\title{
A catalogue of types of Conopoidea, Diopsoidea, Nerioidea and Tephritoidea (Diptera, Schizophora) in the collection of the Museu de Zoologia da Universidade de São Paulo
}

\author{
Ramon Luciano Mello ${ }^{1}$ Carlos José Einicker Lamas ${ }^{1}$
}

${ }^{1}$ Museu de Zoologia da Universidade de São Paulo. Avenida Nazaré, 481 Ipiranga 04263-000 São Paulo-SP, Brasil. ramonlmello@gmail.com.

\begin{abstract}
A catalogue of types of Conopoidea, Diopsoidea, Nerioidea and Tephritoidea (Diptera, Schizophora) in the collection of the Museu de Zoologia da Universidade de São Paulo. A catalogue is provided with the type material of four superfamilies of "Acalyptrate" (Conopoidea, Diopsoidea, Nerioidea and Tephritoidea) held in the collection of the Museu de Zoologia da Universidade de São Paulo (MZUSP), São Paulo, Brazil. Concerning the taxa dealt with herein, the Diptera collection of MZUSP held 77 holotypes, 4 "allotypes" and 194 paratypes. In this paper, information about data labels, preservation and missing structures of the type specimens is given.
\end{abstract}

KEYWORDS. Conopoidea; Diopsoidea; Nerioidea; Tephritoidea; Scientific collections.

RESUMO. Catálogo de tipos de Conopoidea, Diopsoidea, Nerioidea e Tephritoidea (Diptera, Schizophora) da coleção do "Museu de Zoologia da Universidade de São Paulo". É apresentado um catálogo do material tipo de quatro superfamílias de "Acalyptratae" (Conopoidea, Diopsoidea, Nerioidea e Tephritoidea) do acervo da coleção do Museu de Zoologia da Universidade de São Paulo (MZUSP), São Paulo, Brasil. Em relação às superfamílias aqui referidas a coleção do MZUSP possui 77 holótipos, 4 "alótipos" e 194 parátipos. Neste catálogo são disponibilizadas informações sobre etiquetas, preservação e estruturas perdidas dos espécimens.

PALAVRAS-CHAVE. Conopoidea; Diopsoidea; Nerioidea; Tephritoidea; Coleções Científicas.

Following a recommendation of the international Code of Zoological Nomenclature (ICZN 1999: 72F.4), a catalogue of the type material of Conopoidea, Diopsoidea, Nerioidea and Tephritoidea held in the collection of the Museu de Zoologia da Universidade de São Paulo (MZUSP), Brazil is provided. According to McAlpine (1989) these four superfamilies form a monophyletic group in the Acalyptratae section by sharing the following synapomorphies: female abdominal segment 7 developed and forming a bulbous oviscape, and the male aedeagus elongate, flexible, and tending to be looped or coiled (Yeates \& Wiegmann 1999).

The number of types for each family of the Conopoidea, Diopsoidea, Nerioidea and Tephritoidea with holdings in the MZUSP collection is summarized in Table I.

The list given below follows Ribeiro et al. (2007). The type material is listed in alphabetical order of superfamily, family, genus, subgenus, and species name. For each species section, the first line provides the name and authorship; the following lines give the data on the original publication of the name (including figure citations), relevant citations from publications other than the original description, the type locality, and the current taxonomic status. Label data are quoted in double quotation marks. Each line in the text of each label is separated by a vertical line. In case of handwriting on printed labels, the handwritten text is reproduced in italics; completely handwritten and completely printed labels are reproduced in regular font; illegible label information is represented by a question mark. Abbreviated collecting dates and incomplete localities are completed within square brackets. Details on the mode and condition of preservation of the specimens are given, including a list of the missing structures. The terminology for the morphological structures follows McAlpine (1981) and Stuckenberg (1999). The term "allotype" was used in this list only for the specimens which were designated as such in the original description.

Table I. Type material held in the MZUSP

\begin{tabular}{llccc}
\hline Superfamily & \multicolumn{1}{c}{ Family } & Holotype & Allotype* & Paratype \\
\hline Conopoidea & Conopidae & 1 & & 6 \\
Diopsoidea & Syringogastridae & 1 & 1 & 21 \\
Nerioidea & Micropezidae & & & 17 \\
& Neriidae & 3 & 2 & 1 \\
Tephritoidea & Lonchaeidae & 2 & & 1 \\
& Piophilidae & 1 & & 2 \\
& Pyrgotidae & 27 & 1 & 85 \\
& Tephritide & 42 & & 61 \\
\hline Total & & 77 & 4 & 194 \\
\hline
\end{tabular}

* The Allotypes listed here were designated as such in the original descriptions of the species. 


\section{Conopoidea \\ Conopidae}

\section{Baruerizodion steyskali Papavero, 1970}

Papavero (1970), 122-125 (orig. desc.); 123, figs. 1 (head, lateral view), 2 (head, frontal view), 3 (head, dorsal view), 4 (leg III, posterior view), and 5 (abdomen, lateral view). Type locality: Brazil, São Paulo, Barueri.

Holotype female with labels: (1) printed with handwritten inscriptions on white paper: "Barueri|SP, [São Paulo State] Brasil | 7.II.1955 | K. Lenko col.”; (2) printed on red paper: "HOLOTIPO"; (3) handwritten on white paper: "Baruerizodion | steyskali, gen. n., | sp. nov. | Papavero, '69 [1969]'. Preservation: Pinned, left antenna, right trochanter, femora, tibiae and tarsi of legs I and III in a plastic vial pinned with the specimen. Missing parts: none.

\section{Stylogaster lanei Monteiro, 1960}

Monteiro (1960), 104-107 (orig. desc.); 105, figs. 1 (male leg III, posterior view), 2 (male abdomen, lateral view), 3 (male sternite 5), 4 (male terminalia, lateral view), 5 (male terminalia, posterior view), 6 (aedeagus, lateral view), 7 (palpus genital, internal surface), 8 (oviscape, lateral view), 9 (apex of oviscape, lateral view), 10 (egg, lateral view), 11 (egg, anterior region). Camras \& Parrillo, 1985:117, junior synomyn of Stylogaster banski Aldrich. Type locality: Brazil, Amapá, Serra do Navio.

Paratype female with labels: (1) printed with handwritten inscriptions on white paper: "SERRA do NAVIO |Terr. Amapá [Amapá State] BRASIL | 1 X-1957| J. Lane leg.”; (2) printed on pink paper: "PARATYPUS"; (3) handwritten on white paper: "Stylogaster | lanei o | Léa Monteiro Det." Preservation: Pinned. Missing parts: none.

Paratype female with the same labels as in the former Paratype, with label (1) differing in date: "19 X-1957". Preservation: Pinned. Missing parts: none. Paratype male with same labels as in the first Paratype, with label (1) differing in date: "| 21 X-1957 |"; and label (3) differing in the second line: "| lanei $\mathrm{O}^{\prime \mid} \mid$ ". Preservation: Pinned. Missing parts: none.

\section{Stylogaster lepida Lopes \& Monteiro, 1959}

Lopes \& Monteiro (1959), 11-14 (orig. desc.); 13, figs. 36 (male terminalia, lateral view), 37 (male terminalia, dorsal view), 38 (gonostylus, lateral view), 39 (aedeagus, lateral view), 40 (aedeagus, ventral view), 41 (male wing), 42 (male costal vein), 43 (apex of male wing), 44 (leg III, posterior view), 45 (oviscape, lateral view), 46 (apex of oviscape, lateral view), 47 (egg), 48 (egg, anterior extremity). Type locality: Brazil, Rio de Janeiro, Angra dos Reis, Japuíba.

Paratype female with labels: (1) printed on white paper: "Calado-Rio Doce | Minas [Minas Gerais State] 12 a 15. II. 39 [1939] | Martins e Lopes"; (2) printed on pink pa- per: "PARATYPUS"; (3) printed with handwritten inscriptions on white paper: "Stylogaster | lepida n. sp. | Mont \& | Det. H. S. Lopes". Preservation: Pinned. Missing parts: tarsomeres two to five of left leg II and tarsomeres two to five of right leg III.

Paratype female with labels: (1) printed on white paper: "JAPUHYBA | ANGRA [Angra dos Reis] 23-3-940 [III1940] | J. Lane E Lopes"; and with the same labels (2) and (3) as in the former Paratype. Preservation: Pinned, abdomen in a plastic vial pinned with the specimen. Missing parts: none.

Paratype female with labels: (1) handwritten on white paper: "Tinguá | R. Janeiro [Rio de Janeiro State] | 19-4-40 [IV1940]"; and with the same labels (2) and (3) as in the first Paratype. Preservation: Pinned. Missing parts: tarsomeres two to five of legs III.

\section{Diopsoidea Syringogastridae Syringogaster lanei Prado, 1969}

Prado (1969), 6-9 (orig. desc.); 7, fig. 1 (habitus, lateral view); 9, fig. 6 (wing); 11, figs. 11 (head, frontal view), 12 (male postabdome, lateral view), 13 (male terminalia, lateral view), 14 (male terminalia, ventral view), 15 (epandrium, gonostylus and cercus, lateral view), 16 (epandrium, gonostylus and cercus, dorsal view), 17 (female abdomen, tergites 1 to 3 , dorsal view), 18 (female abdomen, tergites 1 to 3, lateral view) and 19 (spermatheca). Type locality: Brazil, São Paulo, Barueri.

Two Paratype males on the same pin with labels: (1) printed with handwritten inscriptions on white paper: "Barueri | São Paulo - Brasil | 14.VII.1955 | K. Lenko col.”; (2) printed with handwritten inscriptions on white paper: "Syringogaster | rufa Cresson | N. Papavero det. ' 62 [1962]"; (3) printed on red paper: "PARATIPO"; (4) printed with handwritten inscriptions on white paper: "Syringogaster | lanei sp. nov. | Det. A. P. Prado | 1969"; (5) printed on white paper: "M". Preservation: Each specimen glued to tip of a pinned card point, first Paratype with right wing glued on respective paper. Missing parts: first Paratype without legs I, right leg II, tarsus of the left leg II and both legs III; second Paratype without head, both legs I, left legs II and III and tibia and tarsus of right leg II.

Paratype male with the same label (1); and with the labels (2) and (3) as the (3) and (4) in the former Paratypes respectively. Preservation: glued to the tip of a pinned card point. Missing parts: none.

Paratype female with the same labels (1) and (2) as in the first Paratypes, with label (1) differing in date: "11.VIII.1955"; (3) printed on white paper: "O"; and with labels (4) and (5) as (3) and (4) in the first Paratype respectively. Preservation: glued to the tip of a pinned card point. Missing parts: left wing. 
Paratype male with labels: (1) printed on white paper: "BARUERI | Est. S. Paulo [São Paulo State] BRASIL | 15.VIII.1957|K. Lenko"; and with the labels (2), (3), (4) and (5) as in the first Paratype. Preservation: Pinned to the tip of a pinned cork. Missing parts: right wing and tarsus of right leg II.

Paratype female with labels (1) and (2) same as above; (3) printed on white paper: "O"; and with labels (4) and (5) same as labels (3) and (4) of the first Paratype respectively. Preservation: Pinned to the tip of a pinned cork. Missing parts: none.

Paratype female with the same labels (1), (2) and (3) as in the first Paratype, but label (1) differing in date: "24.VIII.1955"; (4) printed on white paper: "o"; and with label (5) same as label (4) of the first Paratype. Preservation: glued to the tip of a pinned card point. Missing parts: none.

\section{Syringogaster lopesi Prado, 1969}

Prado (1969), 14-18 (orig. desc.); 7, fig. 3 (male postabdomen, latero-ventral view); 9, fig. 9 (wing); 15, figs. 30 (head, frontal view), 31 (male postabdomen, lateral view), 32 (male terminalia, lateral view), 33 (male terminalia, posterior view), 34 (abdomen segments 7-9, lateral view), 35 (gonostylus, lateral view), 36 (epandrium, gonostylus and cercus, dorsal view), 37 (female abdomen, lateral view), 38 (female abdomen, tergites 1 to 3, dorsal view), 39 (female abdomen, tergites 1 to 3 , lateral view) and 40 (spermathecae). Type locality: Brazil, Bahia, Salvador.

Paratype male with labels: (1) printed on white paper: "Salvador-Bahia | Brasil 20-XI-65 [1965] | H. S. Lopes"; (2) printed on red paper: "PARÁTIPO"; (3) printed with handwritten inscriptions on white paper: "Syringogaster | lopesi; sp. nov. | Det. A. P. Prado | 1969”. Preservation: Pinned. Missing parts: none.

\section{Syringogaster papaveroi Prado, 1969}

Prado (1969), 10-12 (orig. desc.); 7, figs. 2 (male abdomen, lateral view), 4 (female abdomen, ventral view); 9 , fig. 7 (wing); 13, figs. 20 (head, frontal view), 21 (male postabdomen, lateral view), 22 (male postabdomen, without tergite 6, lateral view), 23 (male terminalia, ventral view), 24 (female abdomen, tergites 1 to 3, lateral view), 25 (female abdomen tergites, 1 to 3, dorsal view), 26 (female abdomen, tergites 1 to 3 , dorsal view), 27 (female abdomen, tergites 1 to 3, lateral view) and 28 (spermathecae). Type locality: Brazil, São Paulo, Barueri.

Holotype male with labels: (1) printed with handwritten inscriptions on white paper: "Barueri, | São Paulo, Brasil | 22.I.66 [1966] | K. Lenko col.”; (2) printed on red paper: "Holotypus"; (3) printed with handwritten inscriptions on white paper: "Syringogaster| papaveroi; sp. nov. | Det. A. P. Prado | 1969". Preservation: glued to the tip of a pinned card point. Missing parts: none.
"Allotype" female with the same labels (1), (2) and (3) as in the Holotype, with label (2) differing in: "Allotypus". Preservation: glued to the tip of a pinned card point. Missing parts: none.

Paratype female with the same label (1) as in the Holotype, but differing in date: "26.IV.1955"; (2) printed on white paper: "O";(3) printed on red paper: "PARATIPO"; and with label (4) same as label (3) of the Holotype. Preservation: glued to the tip of a pinned card point. Missing parts: left pedicel and postpedicel.

Four Paratype females with the same labels (1), (2) and (3) as in the Holotype, with the label (2) differing in: "PARATIPO". Preservation: glued to the tip of a pinned card point. Missing parts: none.

Two Paratype males and five females with the same labels (1), (2) and (3) as in the second Paratypes, with label (1) differing in date: "11-VI-1966". Preservation: glued to the tip of a pinned card point. Missing parts: one Paratype female wihout right wing apex.

\section{Nerioidea Micropezidae \\ Protylos littoralis Albuquerque, 1967}

Albuquerque (1967), 241-244 (orig. desc.); 241, figs. 50 (head, dorsal view), 51 (head, lateral view), 52 (mouthparts, lateral view), 53 (antenna), 54 (thorax, lateral view), 55 (wing), 56 (halter, dorsal view), 57 (halter, ventral view), 58 (midcoxa), 59 (male abdomen, lateral view), 60 (male postabdomen, lateral view), 61 (male sternites 57), 62 (male cercus, lateral view), 63 (right gonostylus, ventral view), and 64 (left gonostylus, ventral view); 243, figs. 65 (male terminalia, lateral view); 66 (male terminalia with sternites 5-7, lateral view), 67 (aedeagus, lateral view), 68 (aedeagus, ventral view), 69 (oviscape), 70 (female sternite 7), 71 (female abdomen, lateral view), 72 (spermathecae). Type locality: Brazil, Rio de Janeiro, Guanabara.

Paratype female with labels: (1) printed with handwritten inscriptions on white paper: "BARRA DA TIJUCA | RIO DE JANEIRO | BRASIL H S LOPES | I. 63 [1963]”; (2) handwritten on white paper: Protylos littora- | lis n. sp. | det: Lindalva | P. Albuquerque"; (3) printed on pink paper: "PARATYPUS". Preservation: Pinned. Missing parts: left legs I, II, and III and right leg II.

Paratype female with the same labels (1), (2) and (3) as in the first Paratype, with label (1) differing in date: "10.II.63 [1963]"; and (2) differing in the first line: "Protylos litto-". Preservation: Pinned. Missing parts: left legs II and III.

Two Paratype males with labels: (1) printed with handwritten inscriptions on white paper: "Barra da Tijuca| Rio, [Rio de Janeiro State] Brasil | H.S. LOPES | 13.XII.64 [1964]"; and with the same labels (2) and (3) as in the first Paratype, with label (2) differing in the third and fourth lines: "det: Lindalva P. | Albuquerque". Preserva- 
tion: Pinned. Missing parts: one Paratype without antennae, tarsus of right leg I and of left legs II and III; one Paratype without right pedicel and postpedicel, left halter, femur, tibia and tarsus of left leg II and right legs II and III.

Two Paratype females with the same labels (1), (2) and (3) as in the first Paratype, with label (1) differing in date: "16.I.65 [1965]"; and label (2) differing in the third and fourth lines: "det: Lindalva P. | Albuquerque". Preservation: Pinned. Missing parts: one Paratype without head, femur, tibia and tarsus of the left leg II.

Paratype female with labels: (1) printed with handwritten inscriptions on white paper: "S. Conrado [São Conrado] | Rio [Rio de Janeiro State] Brasil | H.S. LOPES | 14.2.65 [II-1965]"; and with the same labels (2) and (3) as in the first Paratype, with label (2) differing in the third and fourth lines: "det: Lindalva P. | Albuquerque". Preservation: Pinned, thorax left pleurae and abdominal segments $1+2$ and 3 partially damaged. Missing parts: femur, tibia and tarsus of right leg II.

Two Paratype males and one female with the same labels (1), (2) and (3) as in the third Paratypes, with label (1) differing in date: "27.2.65 [II-1965]". Preservation: Pinned. Missing parts: one Paratype male without femur, tibia and tarsus of the right leg II and apical third of right wing; one Paratype male without pedicel and postpedicel of both antennae, femur, tibia and tarsus of right leg III; and the Paratype female without posterior half of both wings.

One Paratype male and one female with the same labels (1), (2) and (3) as in the third Paratypes, with label (1) differing in date: "28.2.65 [II-1965]". Preservation: Pinned. Missing parts: Paratype male without femur, tibia and tarsus of the right leg II and tarsus of right leg III; Paratype female without tibia and tarsus of the right leg I, femur, tibia and tarsus of right leg II.

\section{Protylos reconditus (Albuquerque, 1967)}

Albuquerque (1967), 237-241 (orig. desc.); 238, figs. 25 (head, dorsal view), 26 (head, lateral view), 27 (antenna), 28 (thorax, lateral view), 29 (wing), 30 (halter, dorsal view), 31 (halter, ventral view), 32 (fore leg), 33 (mid leg, posterior view), 34 (mid leg, anterior view), 35 (mid leg, oblique view), 36 (hind leg, posterior view); 239, figs. 37 (male postabdomen, lateral view), 38 (male sternites 6-7, dorsal view), 39 (epandrium, lateral view), 40 (epandrium, dorsal view), 41 (right gonostylus, ventral view), 42 (left gonostylus, ventral view), 43 (aedeagus, lateral view), 44 (female postabdomen, lateral view), 45 (female postabdomen, dorsal view), 46 (oviscape, lateral view), 47 (oviscape, internal view), 48 (female cercus, lateral view) and 49 (spermathecae). Type locality: Brazil, Rio de Janeiro, Tijuca.

Current name: Micropeza (Protylos) reconditus.

Paratype male with labels: (1) printed on white paper: “GRAJAHÚ [Grajaú] | Rio [Rio de Janeiro State] 9.XII.40
[1940] | Lopes \& Machado"; (2) printed on pink paper: "PARATYPUS"; (3) handwritten on white paper: "Protylos recon- | ditus n. sp. | det: Lindalva | P. Albuquerque”. Preservation: Pinned. Missing parts: left pedicel and postpedicel, femora, tibiae and tarsi of right legs I, II and III.

Paratype female with labels: (1) printed on white paper: "Grajahu [Grajaú, Rio de Janeiro State] | 13.III.941 [1941] | Lopes \& Oliveira"; and with the label (2) as the (3) in the first Paratype, differing in the third and fourth lines: "Lindalva P. | Albuquerque"; and with label (3) same as label (2) of the first Paratype. Preservation: Pinned. Missing parts: pedicel and postpedicel of both antennae and femur, tibia and tarsus of the left leg II.

Paratype female with labels: (1) printed with handwritten inscriptions on white paper: "Rio de Janeiro | Tijuca, Brasil | H. S. Lopes | 13.XII.64 [1964]"; and with the same labels (2) and (3) as in the first Paratype, with label (3) deffering in the third and fourth lines: "det: Lindalva P. | Albuquerque". Preservation: Pinned. Missing parts: femur, tibia and tarsus of right leg III.

Paratype male with the same labels (1), (2) and (3) as in the third Paratype, with label (1) differing in date: "14.2.65 [II.1965]”. Preservation: Pinned. Missing parts: femur, tibia and tarsus of the right leg I, tibia and tarsus of the left leg II and femur, tibia and tarsus of left leg III.

Paratype male with the same labels (1) and (2) as in the third Paratype, with label (1) differing in date: "2.3.65 [III.1965]"; (3) handwritten on white paper: "Protylos recondi | tus, n. sp | det: Lindalva Paes | Albuquerque". Preservation: Pinned. Missing parts: tarsus of left leg III.

\section{Neriidae}

\section{Glyphidops (Glyphidops) etele Aczél, 1961}

Aczél (1961), 302-305 (orig. desc.); 303, figs. 33 (head, lateral view), 34 (fore femur, posterior view), and 36 (head, dorsal view). Type locality: Brazil, São Paulo, Juquiá.

Holotype male with labels: (1) printed on white paper: "São Paulo | Juquiá | Dez. [XII] 1946 | M. Carrera”; (2) printed on red paper: "HOLOTIPO"; (3) printed with handwritten inscriptions on white paper: "Glyphidops $\left|\mathrm{O}^{\prime}\right|$ etele $n$. sp. | Dr. M. Aczél det. 19”. Preservation: Pinned. Missing parts: right wing and apical half of left wing.

\section{Glyphidops (Oncopsia) carrerai Aczél, 1961}

Aczél (1961), 316-319 (orig. desc.); 317, figs. 55 (head, lateral view), and 56 (head, dorsal view). Type locality: Brazil, São Paulo, São Vicente, Barreiro.

Holotype male with labels: (1) printed on white paper: "São Paulo | São Vicente | Barreiros | Jan. [I] - 1945 | M. Carrera col."; (2) printed on red paper: "HOLOTIPO"; (3) printed with handwritten inscriptions on white paper: " $G$. (Oncopsia) | $O^{\prime \prime}$ carrerai n. sp. | Dr. M. Aczél det. 19". Preservation: Pinned. Missing parts: femora, tibiae and tarsi of right legs II and III. 


\section{Nerius czernyi Aczél, 1961}

Aczél (1961), 334-336 (orig. desc.); 335, fig. 61 (mesonotum). Type locality: Argentina, Misiones, Puerto Aguirre.

"Allotype" male with labels: (1) handwritten on white paper: "S. Paulo [São Paulo State] | Serra da | Bocaina | VIII - 41 [1941] [lateral inscription]"; (2) printed with handwritten inscriptions on white paper: "Nerius O"| robustus (End.) / Dr. M. Aczél det. 19”; (3) printed on red paper: “ALOTIPO”; (4) printed with handwritten inscriptions on white paper: "Nerius $\sigma^{\prime \prime}$ czernyi n. sp. | Dr. M. Aczél det."; (5) printed on white paper: "z17'. Preservation: Pinned. Missing parts: apical half of the left postpedicel, femur, tibia and tarsi of right leg II and femora, tibiae and tarsi of left legs I, II and III.

\section{Nerius lanei Aczél, 1961}

Aczél (1961), 340-342 (orig. desc.); 335, fig. 63 (mesonotum). Type locality: Brazil, Rio de Janeiro, Angra dos Reis.

Holotype male with labels: (1) printed with handwritten inscriptions on white paper: "BR- [Brazil] R. J.- [Rio de Janeiro State] Angra dos Reis | Faz. [farm] Japuhyba| L. T. F. Agosto[VIII] 1945"; (2) printed on red paper: "HOLOTIPO"; (3) printed with handwritten inscriptions on white paper: "Nerius $\sigma^{\prime \prime}$ lanei n. sp. | Dr. M. Aczél det.”; (4) printed on white paper: "z18". Preservation: Pinned, left leg I glued on first label. Missing parts: tarsus of right leg I.

"Allotype" female with the same label (1) as in the Holotype, differing in the third line: "L. T. F. Junho- [VI] 1945"; with label (2) as (3) in the Holotype, differing in the first line: "Nerius o"; (3) printed on red paper: "ALOTIPO"; (4) printed on white paper: "z19”. Preservation: Pinned. Missing parts: right wing.

Paratype male with the same labels (1) and (3) as in the Holotype, with label (1) differing in the third line: "L. T. F. VIII1945"; (2) printed with handwritten inscriptions on white paper: "INST. M. [Instituto Miguel] LILLO | Preparación | No. 180. M. Ala"; (4) printed on white paper: "PARATIPO"; (5) printed on white paper: "z20". Preservation: Pinned, terminalia dissected and partially mounted on a microslide with a plastic vial pinned on a separate pin with a white label with handwritten: "z20". Missing parts: right wing, femur, tibia and tarsus of left leg I.

\section{Tephritoidea \\ Lonchaeidae}

\section{Dasiops longulus Norrbom \& McAlpine, 1997}

Norrbon \& McAlpine (1997), 205 (orig. desc.). Type locality: Brazil, São Paulo, Santa Isabel.

Holotype male with labels: (1) printed on white paper: "BRAZIL: Sao Paulo: [São Paulo State] | Santa Isabel, passion fruit | (crop*), M. A. Uchoa F."; (2) printed on white paper: "Dasiops | 949 ALN"; (3) printed with handwritten inscriptions on red paper: "HOLOTYPE USNM | Dasiops o $\mid$ longulus $\mid$ Norrbon \& McAlpine". Preservation: Pinned, abdomen in a plastic vial pinned with specimen. Missing parts: none.

\section{Neosilba bifida Striks \& Prado, 2005}

Striks \& Prado (2005), 1-4 (orig. desc.); 2, figs. 1 (male terminalia, lateral view), 2 (male terminalia, ventral view), 3 (detail of spine like on male terminalia, ventral view). Type locality: Brazil, São Paulo, São Bento do Sapucai.

Holotype male with label: (1) printed on white paper: "Brazil, São Paulo | São Bento do Sapucaí | 31.I.1996 Miguel de |Souza Filho col."; (2) printed on red paper: "Holotipo". Preservation: fixed in a plastic vial pinned with label. Missing parts: none.

Paratype male with the same label (1) as in the Holotype; (2) printed on green paper: "Paratypo". Preservation: fixed in a plastic vial pinned with label. Missing parts: none.

\section{Piophilidae}

\section{Bocainamyia hagmannarum Papavero \& Val, 1971}

Papavero \& Val (1971), 106-09 (orig. desc.); 107, figs. 1 (head, frontal view), 2 (head, dorsal view), 3 (head, lateral view), 4 (male scutellum, dorsal view), 5 (female scutellum, dorsal view), and 6 (wing); 108, figs. 7 (male terminalia, posterior view), 8 (male terminalia, lateral view), 9 (male tergite 10, dorsal view), 10 (male terminalia without tergite 10 , posterior view), and 11 (male terminalia without tergite 10, lateral view). Type locality: Brazil, Pará, Santarém, Fazenda Taperinha.

Holotype male with labels: (1) printed on white paper: "Fazenda Taperinha | Santarém, PA [Pará State]| Brasil X-XI.1970 | Exp. Perm. Amaz. [Amazon Permanent Expedition]"; (2) printed on red paper: "HOLOTIPO"; (3) printed with handwritten inscriptions on white paper: "Bocainamyia $\mid$ hagmannarum $\mid N$. Papavero e |F. C. Val det. '70 [1970]”. Preservation: Pinned. Missing parts: apex of right wing and tibia and tarsus of left leg III.

Paratype female with the same labels (1), (2) and (3) as in the Holotype, with label (2) differing in: "PARATIPO". Preservation: Pinned. Missing parts: none.

Paratype male with labels: (1) handwritten on white paper: "Maloquinha, PA [Pará State] | prx. Itaituba|XI-70 [1970] EPA [Amazon Permanent Expedition]"; and with the same labels (2) and (3) as in the first Paratype. Preservation: Pinned, postabdomen in a plastic vial pinned separately from the specimen. Missing parts: none.

\section{Pyrgotidae}

\section{Carrerapyrgota aczeli Mello, Lamas \& Rafael, 2010}

Mello, Lamas \& Rafael (2010), 47-51 (orig. desc.); 48, figs. 1A (habitus, lateral view), 1B (head, dorsal view), 1C (head, lateral view); 48, 2A (palpus, dorsal view); 49, 3A 
(fore femur, posterior view); 50, 4A (wing); 50, 5A (male sternite 5); 51, figs. 6A (male terminalia, posterior view), 6B (male terminalia, lateral view), 6C (ejaculatory apodeme), 6D (apex of phallus, lateral view), 6E (oviscape, ventral view), 6F (oviscape, lateral view), and 6G (aculeus, ventral view). Type locality: Brazil, São Paulo, Salesópolis, Estação Biológica de Boracéia.

Holotype: female with labels: (1) printed on white paper: "BRASIL-S. Paulo. [São Paulo State] | Boracea [Boracéia] XI-1941 | Almeida coll.”; (2) printed on red paper: "HOLOTIPO". Preservation: Pinned. Missing parts: tarsomeres four to five of left leg I, tarsus of right leg II and tarsomeres three to five of right leg III.

Paratype male with labels: (1) printed on white paper: "THEREZOPOLIS | E. DO RIO [Rio de Janeiro State] 1940 | TRAV. E FREITAS”; (2) printed on green paper: "PARÁTIPO". Preservation: Pinned, abdomen in a plastic vial pinned with the specimen. Missing parts: tarsus of right leg II.

Paratype male with labels: (1) printed on white paper: "Salesópolis, SP [São Paulo State] | Est. Biológica Boracéia |X.1995 | DZUSP”; (2) same as the former. Preservation: Pinned. Missing parts: none.

Paratype female with labels: (1) printed with handwritten inscriptions on white paper: "Itatiaya [Itatiaia] - 700m Est. do Rio [Rio de Janeiro State] | Brasil Lic? [characters undistinguishable] | 11.- XII: 38 [1938]. | J. F. Zikán [lateral inscription]."; (2) same as the former. Preservation: Pinned, both wings damaged in posterior half. Missing parts: femur, tibia and tarsus of left leg III.

Paratype female with labels: (1) printed with handwritten inscriptions on white paper: "ITATIAYA, [Itatiaia] 700m | Est. do Rio. [Rio de Janeiro State] Brasil | 5: III; 1939 ? [character undistinguishable] | J. F. Zikán [lateral inscription].”; (2) same as the former. Preservation: pinned. Missing parts: none.

Paratype female with labels: (1) printed on white paper: "São Paulo | Campos do Jordão | Lefevre 1200 ms.”; (2) handwritten on white paper: "II-1953| L. Travassos Fæ\%"; (3) printed on green paper: "PARÁTIPO". Preservation: Pinned. Missing parts: tarsomeres two to five of right leg I.

Paratype female with labels: (1) printed on white paper: "COLEÇÃO | CAMPOS SEABRA"; (2) printed with handwritten inscriptions on white paper: "CORUPÁ $\mid$ S. Catarina [Santa Catarina State] BRASIL | XI:1955 | A. Maller"; (3) same as the former. Preservation: Pinned. Missing parts: none.

Paratype female with labels: (1) printed with handwritten inscriptions on white paper: "BARUERI $\mid$ S. Paulo [São Paulo State] BRASIL | 15-XII-1958| K. Lenko leg."; (2) handwritten on white paper: "Na Luz [at light]"; (3) same as the former. Preservation: Pinned, right wing and abdomen in a plastic vial pinned with the specimen. Missing parts: tarsomeres two to five of left leg III.

Paratype female with labels: (1) printed with handwritten inscriptions on white paper: "Est. Biol. [Biological Sta- tion] Boracéia | Salesopólis, SP- Br. [São Paulo State Brazil] | 22-24.X.82 [1982] Luz | Exc. DZUSP col."; (2) printed on green paper: "PARÁTIPO". Preservation: Pinned. Missing parts: none.

Paratype female with labels: (1) printed on white paper: "Salesópolis, SP [São Paulo State] | Est. Biológica Boracéia |X.1995 | DZUSP”; (2) same as the former. Preservation: Pinned. Missing parts: abdomen after segment 4.

\section{Carrerapyrgota bernardii Mello, Lamas \& Rafael, 2010}

Mello, Lamas \& Rafael (2010), 51-55 (orig. desc.); 48, 2B (palpus, dorsal view); 49, 3 B (fore femur, posterior view); 50, 4B (wing); 50, 5B (male sternite 5); 52, figs. 7A (habitus, lateral view), 7B (head, frontal view), 7C (head, dorsal view), 7D (head, lateral view); 53, figs. 8A (male terminalia, posterior view), 8B (male terminalia, lateral view), 8C (ejaculatory apodeme), 8D (apex of phallus, lateral view), 8E (oviscape, ventral view), 8F (oviscape, lateral view), and 8G (aculeus, ventral view). Type locality: Brazil, Bahia, Encruzilhada.

Holotype: male with labels: (1) printed on white paper: "ENCRUZILHADA | DIVISA 960 m | BAHIA BRASIL"; (2) printed with handwritten inscriptions on white paper: "SEABRA \& ROPPA |XI - 72 [1972]"; (3) printed on red paper: "HOLÓTIPO". Preservation: Pinned. Missing parts: femur, tibia and tarsus of left leg II.

Four Paratype males and eight females with the same labels (1) and (2) as in the Holotype; (3) printed on green paper: "PARÁTIPO". Preservation: Pinned. Missing parts: one Paratype female without left pedicel and flagellomere, right flagellomere, tibia and tarsus of left leg II; one Paratype female without femur, tibia and tarsus of right leg I.

Ten Paratype males and 19 females with labels: (1) printed on white paper: "ENCRUZILHADA | BAHIA BRASIL"; and with the same labels (2) and (3) as in the first Paratypes. Preservation: Pinned. Missing parts: one Paratype male without left arista; one Paratype male without arista, femur, tibia and tarsus of left leg II and tarsomeres three to five of right leg III; one Paratype male without apex of left arista and apex of right wing; one Paratype male without apex of left wing; one Paratype female without tarsi of left legs II and III; one Paratype female without tarsus of right leg II and tarsomeres two to five of right leg III; one Paratype female without posterior region of right wing.

Five Paratype females with labels: (1) printed on white paper: "PEDRA AZUL | MINAS, [Minas Gerais State] BRASIL"; (2) printed with handwritten inscriptions on white paper: "SEABRA \& | Oliveira $\mid X I-72$ [1972]"; (3) printed on green paper: "PARÁTIPO". Preservation: Pinned. Missing parts: one Paratype without tarsomeres three to five of right leg I.

Nine Paratype males and 10 females with labels: (1) Printed on white paper: "BRASIL, BA, [Bahia State] Encruzilhada | 15³2’25”S - 4050’12”W | 10-12.xii.2007”; (2) printed on white paper: “J. A. Rafael; P. C. Grossi \& |D. R. Parizoto 
col. | Aramadilha Luminosa, 800m"; (3) Printed on green paper: "PARÁTIPO". Preservation: Pinned. Missing parts: one Paratype male without femora, tibiae and tarsi of right legs II and III; one Paratype male without left postpedicel.

\section{Carrerapyrgota miliaria Aczél, 1956}

Aczél (1956b), 21-26 (orig. desc.); 22, figs. 84 (head, lateral view), 85 (head, frontal view), 86 (head, dorsal view) 87 (male postabdomen, lateral view), 88 (male postabdomen, dorsal view), 89 (epandrium, dorsal view), 90 (female abdomen, lateral view), 91 (oviscape, dorsal view), 92 (oviscape, ventral view) and 24, fig. S (wing). Mello et al. (2010), 55-58 (redesc.); 48, 2C (palpus, posterior view); 49, 3C (fore femur, posterior view); 50, 4C (wing); 50, 5C (male sternite 5); 56, 9A (habitus, lateral view), 9B (head, frontal view), 9C (head, dorsal view), 9D (head, lateral view); 57, figs. 10A (male terminalia, posterior view), 10B (male terminalia, lateral view), 10C (ejaculatory apodeme), 10D (apex of phallus, lateral view), 10E (oviscape, ventral view), $10 \mathrm{~F}$ (oviscape, lateral view), and 10G (aculeus, ventral view). Type locality: Brazil, Mato Grosso do Sul, Salobra.

Holotype male with labels: (1) printed on white paper: "Mato Grosso [Mato Grosso do Sul State] | Salobra | X-1938, F. Lane"; (2) printed with handwritten inscriptions on white paper: "Carrerapyrgota | miliaria n. sp. O"| Dr. M. Aczél det. 19"; (3) printed on red paper: "HOLOTIPO”. Preservation: Pinned. Missing parts: femur, tibia and tarsus of left leg I.

\section{Idiopyrgota setiventris Aczél, 1956}

Aczél, (1956b), 16-20 (orig. desc.); 18, figs. 78 (head, lateral view), 79 (head, dorsal view), 80 (right antenna, anterior view), 81 (left fore femur, posterior view), 82 (female abdomen, lateral view), 83 (oviscape, dorsal view) and 24 fig. R (wing). Mello \& Lamas (2008), 59-64 (redesc.); 61, figs. 1A (habitus), 1B (head, frontal view), $1 \mathrm{C}$ (head, lateral view), 1D (thorax, dorsal view), 1E (fore femur, anterior view), $1 \mathrm{~F}$ (wing); 62, figs. 2A (male postabdomen, lateral view), $2 \mathrm{~B}$ (male terminalia, lateral view), 2C (male terminalia, posterior view), 2D (male terminalia, ventral view), 3A (female postabdomen, lateral view), 3B (oviscape, ventral view), 3C (aculeus, ventral view), 3D (spermathecae). Type locality: Brazil, Mato Grosso do Sul, Salobra.

Holotype female with labels: (1) printed on white paper: "Com. I.O.C. [Commission Instituto Oswaldo Cruz] BRASIL | Mato Grosso- [Mato Grosso do Sul State] Salobra 24.8 a 6.9 [24.VIII to 6.IX] - 1940"; (2) printed with handwritten inscriptions on white paper: "Idiopyrgota n. g. | setiventris n. sp. | Dr. M. Aczél det. 1"; (3) printed on red paper: "HOLOTIPO". Preservation: Pinned. Missing parts: none.

Paratype female with labels: (1) printed on white paper: "Mato Grosso- [Mato Grosso do Sul State] | Salobra |X1938, F. Lane"; with the same label (2) as in the Holotype, differing in the first line: "Idiopyrgota o"; (3) printed on white paper: "PARATIPO". Preservation: Pinned, tibia and tarsus of the right leg $I$ in a plastic vial pinned with the specimen. Missing parts: none.

Paratype female with the same labels (1) and (2) as in the Holotype, with label (2) differing in the second line: "O"; (3) printed on white paper: "PARATIPO". Preservation: Pinned. Missing parts: antennae. Two Paratypes females with the same labels (1) and (2) as in the holotype; (3) same as the former". Preservation: Pinned. Missing parts: none.

\section{Leptopyrgota accolens Bernardi, 1991}

Bernardi (1991), 331-332 (orig. desc.); 329, fig. 4 (head, lateral view). Type locality: Brazil, São Paulo, São José dos Campos.

Holotype female with labels: (1) printed on white paper: "S. JOSE DOS CAMPO [São José dos Campos] | EST. S. PAULO [São Paulo State] | H. S. Lopes XII-934 [1934]"; (2) handwritten on white paper: "L. accolens"; (3) printed on red paper: "HOLÓTIPO”. Preservation: Pinned. Missing parts: tarsus of right leg II.

\section{Leptopyrgota albitarsis Aczél, 1956}

Aczél (1956a), 42-46 (orig. desc.); 43, figs. 28 (head, dorsal view), 29 (head, lateral view), 30 (right antenna, anterior view), and 31 (epandrium, lateral view). Type locality: Brazil, São Paulo, Campos do Jordão.

Holotype female with labels: (1) printed on white paper: "BR[Brazil] S. P.: [São Paulo State] Campos Jordão [Campos do Jordão] | Eug. [Eugene] Lefevre 1.200m | 18-outubro[X] 1952 |d'Almeida \& L.T.F.”; (2) printed with handwritten inscriptions on white paper: "Leptopyrgota $\mathrm{O}^{\prime} \mid$ albitarsis $n$. sp. | Dr. M. Aczél det.”; (3) printed on red paper: "HOLOTIPO". Preservation: Pinned. Missing parts: none. "Allotype" male with the same labels (1), (2) and (3) as in the Holotype, with label (3) differing in: "ALOTIPO". Preservation: Pinned. Missing parts: none. Paratype male with the same labels (1) and (2) as in the Holotype; (3) printed on white paper: "PARATIPO"; (4) handwritten on white paper: " $O$ ". Preservation: Pinned, left wing pinned between labels three and four. Missing parts: femora, tibiae and tarsi of legs II and III and abdomen.

Two Paratype females with the same labels (1) and (2) as in the "Allotype"; (3) printed on white paper: "PARATIPO". Preservation: Pinned. Missing parts: one Paratype without right wing.

\section{Leptopyrgota andrei Bernardi, 1991}

Bernardi (1991), 336-337 (orig. desc.); 333, figs. 12 (head, lateral view), 13 (oviscape, lateral view), and 14 (oviscape, dorsal view). Type locality: Brazil, São Paulo, Salesópolis, Estação Biológica de Boracéia. 
Holotype female with labels: (1) printed with handwritten inscriptions on white paper: "Est. Biol. [Biological Station] Boracéia | Salesópolis | São Paulo - Brasil | 11. XI. 1960. K. Lenko col"; (2) printed on red paper: "HOLÓTIPO". Preservation: Pinned. Missing parts: tarsomeres four to five of left leg III.

\section{Leptopyrgota apposita Bernardi, 1991}

Bernardi (1991), 328-330 (orig. desc.); 329, fig. 1 (head, lateral view). Type locality: Brazil, Santa Catarina, Pinhal.

Holotype female with labels: (1) printed with handwritten inscriptions on white paper: "PINHAL $\mid$ S. Catarina [Santa Catarina State] BRASIL | XII. $1955 \mid$ A. Maller”; (2) handwritten on white paper: "L. apposita"; (3) printed on red paper: "HOLÓTIPO". Preservation: Pinned. Missing parts: left palpus and tarsi of right legs II and III.

\section{Leptopyrgota brevipennis Bernardi, 1991}

Bernardi (1991), 346-347 (orig. desc.); 345, fig. 26 (head, lateral view). Type locality: Brazil, São Paulo, Barueri.

Holotype male with labels: (1) printed with handwritten inscriptions on white paper: "BARUERI | S. Paulo [São Paulo State] BRASIL $\mid$ XI. 1966 | K. Lenko leg."; (2) handwritten on white paper: "L. brevipennis"; (3) printed on red paper: "HOLÓTIPO”. Preservation: Pinned. Missing parts: head, right wing, apex of left wing and femur, tibia and tarsi of right leg II.

\section{Leptopyrgota caelifera Bernardi, 1991}

Bernardi (1991), 348-349 (orig. desc.). Type locality: Brazil, São Paulo, Itu.

Holotype male with labels: (1) printed with handwritten inscriptions on white paper: "Faz. [farm] Pau D' Alho | Itu São Paulo | Brasil | 1-5/XI/61 [1961] | U. Martins- / Kloss e Silva col."; (2) printed on red paper: "HOLÓTIPO". Preservation: Pinned, with a hole on the right side of segments 4 and 5 of abdomen. Missing parts: apex of right arista, posterior half of right wing, halteres, apex of tibia and tarsus of right leg I.

\section{Leptopyrgota celeriuscula Bernardi, 1991}

Bernardi (1991), 330-331 (orig. desc.); 329, figs. 2 (head, lateral view), and 3 (oviscape, dorsal view). Type locality: Brazil, São Paulo, Barueri.

Holotype male with labels: (1) printed with handwritten inscriptions on white paper: "BARUERI | S. Paulo [São Paulo State] BRASIL $\mid$ XII. $1966 \mid$ K. Lenko leg."; (2) handwritten on white paper: "L. celeriuscula"; (3) handwritten on white paper: "L. celeriuscula | holótipo"; (4) printed on red paper: "HOLÓTIPO". Preservation: Pinned. Missing parts: none.

\section{Leptopyrgota cocta Bernardi, 1991}

Bernardi (1991), 335-336 (orig. desc.); 333, fig. 11 (head, lateral view). Type locality: Brazil, Santa Catarina, Pinhal.

Holotype male with labels: (1) printed with handwritten inscriptions on white paper: "PINHAL $\mid$ S. Catarina [Santa Catarina State] BRASIL | XII. 1955 | A. Maller"; (2) printed on red paper: "HOLÓTIPO". Preservation: Pinned. Missing parts: costal area of right wing, apical 2/3 of left wing, femur, tibia and tarsus of right leg II and tarsomeres three to five of left leg III.

\section{Leptopyrgota definienda Bernardi, 1991}

Bernardi (1991), 334-335 (orig. desc.); 333, figs. 9 (head of male, lateral view), and 10 (head of female, lateral view). Type locality: Brazil, Rio de Janeiro, Itatiaia.

Holotype male with labels: (1) printed with handwritten inscriptions on white paper: "ITAIAYA, [Itatiaia] 700m | Est. do Rio. [Rio de Janeiro State] Brasil | 1:XII:1947? [character undistinguishable] | F. Zikán [lateral inscription]"; (2) handwritten on white paper: "Ơ"; (3) printed on red paper: "HOLÓTIPO". Preservation: Pinned. Missing parts: abdomen.

Paratype female with labels: (1) printed with handwritten inscriptions on white paper: "Itatiaya- [Itatiaia] 700m | Est. do Rio [Rio de Janeiro State] | Brasil licht |21:XII:29 [1929] | J. F. Zikán [lateral inscription]"; (2) handwritten on white paper: "33”; (3) handwritten on blue paper: "5."; (4) handwritten on green paper: "PARÁTIPO”. Preservation: Pinned, left wing broken in the middle. Missing parts: femora, tibiae and tarsi of left legs I and II and tarsus of left leg III.

\section{Leptopyrgota ensifera Bernardi, 1991}

Bernardi (1991), 332-334 (orig. desc.); 329, figs. 6 (head, lateral view), and 7 (oviscape, dorsal view). Type locality: Brazil, São Paulo, Cajuru, Cássia dos Coqueiros.

Holotype female with labels: (1) printed on white paper: "Cássia dos Coquieros, | Mun. Cajuru [Cajurú municipality], SP [São Paulo State] | Brasil. II-1955 | M. P. Barretto col.”; (2) handwritten on white paper: "L. ensifera"; (3) printed on red paper: "HOLÓTIPO”. Preservation: Pinned, base of right wing partially destroyed. Missing parts: left wing.

\section{Leptopyrgota flavipes Bernardi, 1991}

Bernardi (1991), 344-346 (orig. desc.); 345, fig. 24 (head, lateral view). Type locality: Brazil, São Paulo, Campos do Jordão.

Holotype male with labels: (1) printed on white paper: "São Paulo | Campos do Jordão"; (2) handwritten on white paper: "XII-52 [1952] | L. travassos Fo"; (3) handwritten on white paper: "L. flavipes"; (4) printed on red paper: "HOLÓTIPO". Preservation: Pinned. Missing parts: right arista. 


\section{Leptopyrgota gracilenta Bernardi, 1991}

Bernardi (1991), 343-344 (orig. desc.); 342, fig. 23 (head, lateral view). Type locality: Brazil, São Paulo, São Paulo.

Holotype female with labels: (1) handwritten on white paper: "São Paulo | Sto [Santo] Amaro | J. Lane-col. | XII-54 [1954] [lateral inscription]"; (2) handwritten on white paper: "L. gracilenta"; (3) printed on red paper: "HOLÓTIPO". Preservation: Pinned. Missing parts: femora, tibiae and tarsi of left legs II and III and tarsomeres two to five of right leg III.

\section{Leptopyrgota hesterna Bernardi, 1991}

Bernardi (1991), 349-350 (orig. desc.). Type locality: Brazil, São Paulo, Campos do Jordão.

Holotype male with labels: (1) printed on white paper: "São Paulo | Campos do Jordão"; (2) handwritten on white paper: "Jan_ [I] $1953 \mid$ L. Travassos Fo"; (3) handwritten on white paper: "L. hesterna"; (4) printed on red paper: "HOLÓTIPO". Preservation: Pinned. Missing parts: right wing and halter, tibia and tarsus of right leg II, femora, tibiae and tarsi of legs III and abdomen.

\section{Leptopyrgota isabelae Bernardi, 1991}

Bernardi (1991), 343 (orig. desc.); 342, figs. 20 (oviscape, dorsal view), 21 (oviscape, lateral view), and 22 (head, lateral view). Type locality: Brazil, São Paulo, Ribeirão Preto.

Holotype female with labels: (1) printed on white paper: "Rio Tamanduá | Ribeirão Preto. SP [São Paulo State] | Brasil X-1953 | M. P. Barretto col."; (2) handwritten on white paper: "L. abcisa"; (3) printed on red paper: "HOLÓTIPO". Preservation: Pinned. Missing parts: left halter, femur, tibia and tarsus of right leg III.

\section{Leptopyrgota juniae Bernardi, 1991}

Bernardi (1991), 340-341 (orig. desc.); 342, fig. 18 (head, lateral view). Type locality: Brazil, Rio de Janeiro, Itatiaia.

Holotype male with labels: (1) printed with handwritten inscriptions on white paper: "ITATIAYA [Itatiaia], $700 \mathrm{~m}$.| Est. do Rio [Rio de Janeiro State]. Brasil | 22: I: 1933 T. | J. F. Zikán [lateral inscription]"; (2) handwritten on white paper: "237"; (3) handwritten on white paper: "L. juniae"; (4) printed on red paper: "HOLÓTIPO". Preservation: Pinned. Missing parts: none.

\section{Leptopyrgota lenkoi Bernardi, 1991}

Bernardi (1991), 346 (orig. desc.); 345, fig. 25 (head, lateral view). Type locality: Brazil, São Paulo, Barueri.

Holotype male with labels: (1) handwritten on white paper: “23.XII.1956 | Barueri/Est. | de S. Paulo [São Paulo State]/ .| Karol Lenko-leg."; (2) handwritten on white paper: "L. lenkoi"; (3) printed on red paper: "HOLÓTIPO”. Preservation: Pinned. Missing parts: left postpedicel, right wing and halter, anal region of left wing, tarsomeres four to five of left leg I, femur, tibia and tarsus of left leg II, tarsomeres four to five of right leg II, femur, tibia and tarsus of right leg III and tarsus of left leg III.

\section{Leptopyrgota liae Bernardi, 1991}

Bernardi (1991), 341-342 (orig. desc.); 329, fig. 8 (oviscape, dorsal view); 342, fig. 19 (head, lateral view). Type locality: Brazil, Santa Catarina, Nova Teotônia.

Holotype female with labels: (1) printed with handwritten inscriptions on white paper: "Brasilien [Brazil] | Nova Teutonia | $27^{\circ} 11^{\prime} \mathrm{B} 52^{\circ} 23^{\prime} \mathrm{L} \mid$ Fritz Plaumann | $300-500$ m [lateral inscription] | IX. 19671 [1971]"; (2) handwritten on white paper: "L. Raquel"; (3) printed on red paper: "HOLÓTIPO". Preservation: Pinned, costal area of both wing partially destroyed. Missing parts: tarsomeres four to five of left leg III, femora, tibiae and tarsi of right legs II and III.

\section{Leptopyrgota marci Bernardi, 1991}

Bernardi (1991), 337-339 (orig. desc.); 333, fig. 15 (head, lateral view). Type locality: Brazil, São Paulo, Salesópolis, Estação Biológica de Boracéia.

Holotype male with labels: (1) printed on white paper: "BRS.P.: [Brazil, São Paulo State] Salesópolis | Boracea [Boracéia] 15.XII.1947 | E. Rabelo col."; (2) handwritten on white paper: "L. newtoni?"; (3) printed on red paper: "HOLÓTIPO". Preservation: Pinned, costal area of both wing partially destroyed. Missing parts: tarsomeres three to five of left leg III.

Paratype female with labels: (1) printed on white paper: "Light trap"; (2) printed with handwritten inscriptions on white paper: "Est. Biol. [Biological Satation of] Boracéia | Salesópolis S.P. [São Paulo State] | 21-25/X/63 [1963] | J. H. Guimarães col."; (3) handwritten on white paper: "L. flacita"; (4) printed on green paper: "PARÁTIPO". Preservation: Pinned. Missing parts: apex of right arista, apex of left wing and anal region of right wing.

\section{Leptopyrgota minensis Bernardi, 1991}

Bernardi (1991), 348 (orig. desc.); 345, figs. 29 (tibia) and 30 (head, lateral view). Type locality: Brazil, Minas Gerais, Pouso Alegre.

Holotype female with labels: (1) handwritten on white paper: "Minas Gerais | Pouso Alegre | P. Pereira col. | I-946 [1946] [lateral inscription]"; (2) handwritten on white paper: L. minensis"; (3) printed on red paper: "HOLÓTIPO". Preservation: Pinned, left wing partially broken on basal third. Missing parts: apex of left arista, tarsomeres four to five of right legs II and III. 


\section{Leptopyrgota quaerens Bernardi, 1991}

Bernardi (1991), 332 (orig. desc.); 329, fig. 5 (head, lateral view). Type locality: Brazil, Minas Gerais, Jaboticatubas, Serra do Cipó.

Holotype male with labels: (1) handwritten on white paper: "Jaboticabas [Jaboticatubas] | S. [Serra] do Cipó, MG [Minas Gerais State] | X-1975 | Vanin \& Froehlich”; (2) printed on red paper: "HOLÓTIPO". Preservation: Pinned. Missing parts: left pedicel and postpedicel, femur, tibia and tarsus of left leg II, tarsomeres four to five of left leg III.

\section{Leptopyrgota sarae Bernardi, 1991}

Bernardi (1991), 339-340 (orig. desc.); 333, figs. 16 (head, lateral view), and 17 (oviscape, lateral view). Type locality: Brazil, Rio de Janeiro, Itatiaia.

Holotype female with labels: (1) printed with handwritten inscriptions on white paper: "ITATIAYA [Itatiaia], 700m | Est. do Rio [Rio de Janeiro State]. Brasil | 23. 1. [I] 1944 T. | J. F. Zikán [lateral inscription]"; (2) handwritten on white paper: "Topica $\mid$ sp. nov."; (3) printed on red paper: "HOLÓTIPO". Preservation: Pinned, right wing broken and folded at base. Missing parts: left pedicel and postpedicel, femur, tibia and tarsus of left leg III.

Paratype female with labels: (1) printed with handwritten inscriptions on white paper: "Itatiaya- [Itatiaia] 700m | Est. do Rio [Rio de Janeiro State]. | Brasil Licht [light] | 17. XII. 29 [1929] | J. F. Zikán [lateral inscription]"; (2) handwritten on white paper: "L. topica"; (3) printed on green paper: "PARÁTIPO". Preservation: Pinned, right wing with costal area partially destroyed. Missing parts: right legs II and III, tarsus of left leg II and tarsomeres three to five of left leg III.

\section{Leptopyrgota tibialis Bernardi, 1991}

Bernardi (1991), 347-348 (orig. desc.); 345, figs. 27 (head, lateral view), and 28 (tibia). Type locality: Brazil, Rio de Janeiro, Itatiaia.

Holotype female with labels: (1) printed on white paper: "Itatiaia, Est do Rio [Rio de Janeiro State], Brasil | (L. 41, 1300m.) Trav. [Travassos], | Albuquerque \& Pearson | 10/12-10- 950 [X. 1950]"; (2) handwritten on white paper: "L. tibialis"; (3) printed on red paper: "HOLÓTIPO". Preservation: Pinned. Missing parts: femur, tibia and tarsus of right leg II.

\section{Neopyrgota (Allopyrgota) hennigi Aczél, 1956}

Aczél (1956b), 12-15 (orig. desc.); 14, figs. 75 (head, lateral view), 76 (head, dorsal view), 77 (epandrium, posterior view). Type locality: Brazil, São Paulo, Campos do Jordão.

Holotype male with labels: (1) printed on white paper: "BR[Brazil] S. P.: [São Paulo State] Campos Jordão [Campos do Jordão] | Eug. [Eugene] Lefevre 1.200m | 18-outubro[X] 1952 d'Almeida \& L.T.F."; (2) printed with handwritten inscriptions on white paper: "Inst. M. [Instituto Miguel] Lillo | Preparación | No 217 M. Ala"; (3) printed with handwritten inscriptions on white paper: "Neopyrgota $\mathrm{O}^{\prime} \mid$ hennigi n. sp. | Dr. M. Aczél det."; (4) printed on red paper: "HOLOTIPO". Preservation: Pinned, left wing mounted on a slide deposited in IMLA [Instituto y Fundación Miguel Lillo Argentina]. Missing parts: none.

\section{Tephritidae Anastrepha amita Zucchi, 1979}

Zucchi (1979a), 35 (orig. desc.); 36, fig. 1 (oviscape apex, ventral view); 38, fig. 12 (wing). Type locality: Brazil, Bahia, Cruz das Almas.

Holotype female with labels: (1) printed on violet paper: "HOLOTYPE"; (2) printed with handwritten inscription on white paper: "Anastrepha $\mid$ amita $\mid$ det. Zucchi”; (3) handwritten on white paper: "Cruz das Almas - BA [Bahia State] $\mid$ frasco caça mosca $\mid$ sem data $\mid$ A. S. Nascimento col.". Preservation: Pinned, abdomen in plastic vial pinned with the specimen. Missing parts: tarsus of right leg III.

\section{Anastrepha barrettoi Zucchi, 1979}

Zucchi (1979a), 35 (orig. desc.); 36, fig. 2 (oviscape apex, ventral view); 38, fig. 13 (wing). Type locality: Brazil, São Paulo, Araçatuba.

Holotype female with labels: (1) handwritten on violet paper: "HOLOTIPO"; (2) printed with handwritten inscription on white paper: "Anastrepha $\mid$ barretoi $\mid$ det. Zucchi"; (3) printed with handwritten inscription on white paper: "Est. S. Paulo [São Paulo State] | Araçatuba | Córrego Azul | Barreto col.”. Preservation: Pinned, abdomen in a plastic vial pinned with the specimen; left wing partially damaged and right one with an incision on costal area. Missing parts: none.

\section{Anastrepha belenensis Zucchi, 1979}

Zucchi (1979a), 36-37 (orig. desc.); 36, fig. 3 (oviscape apex, ventral view); 38, fig. 14 (wing). Type locality: Brazil, Pará, Belém.

Holotype female with labels: (1) handwritten on violet paper: "HOLOTIPO"; (2) printed with handwritten inscription on white paper: "Anastrepha $\mid$ belenensis $\mid$ det. Zucchi"; (3) handwritten on white paper: "Belém - PA [Pará State] | sem data coleta | A. B. da Silva col.”; (4) printed with handwritten inscription on white paper: "N. ${ }^{\circ}$ 224". Preservation: Pinned, abdomen in a plastic vial pinned with the specimen. Missing parts: left leg III.

\section{Anastrepha matertela Zucchi, 1979}

Zucchi (1979a), 37 (orig. desc.); 36, fig. 4 (oviscape apex, ventral view); 38, fig. 15 (wing). Type locality: Brazil, Bahia, Cruz das Almas. 
Holotype female with labels: (1) printed on violet paper: "HOLOTYPE; (2) printed with handwritten inscription on white paper: "Anastrepha $\mid$ matertela $\mid$ det. Zucchi"; (3) handwritten on white paper: "Cruz das Almas - BA [Bahia State] | Chapadinha | frasco caça mosca $\mid$ A. S. Nascimento col. | 10/VIII/1987 [1977] [lateral inscription]". Preservation: Pinned, abdomen in a plastic vial pinned with the specimen. Missing parts: none.

\section{Anastrepha megacantha Zucchi, 1984}

Zucchi (1984), 279-280 (orig. desc.); 280, figs. 1 (wing), 2A (rasper, dorsal view), and 2B (rasper, lateral view). Type locality: Brazil, Amazonas.

Holotype female with labels: (1) handwritten on violet paper: "Holótipo o"; (2) printed with handwritten inscription on white paper: "Anastrepha $\mid$ megacanta Zucchi $\mid$ R. A. Zucchi det. 1984"; (3) handwritten on white paper: "Ducke, Amazonas | Light trap 15 m | 15/6/79 [VI/1979] J. Arias". Preservation: Pinned, abdomen in a plastic vial pinned with the specimen. Missing parts: right leg II and both legs III.

\section{Anastrepha mixta Zucchi, 1979}

Zucchi (1979a), 37 (orig. desc.); 36, fig. 5 (oviscape apex, ventral view); 38, fig. 16 (wing). Type locality: Brazil, Mato Grosso, Utiariti.

Holotype female with labels: (1) printed on violet paper: "HOLOTYPE"; (2) printed with handwritten inscription on white paper: "Anastrepha $\mid$ mixta $\mid$ det. Zucchi"; (3) printed on white paper: "Utiariti $\mid$ Rio Papagaio, Mt [Mato Grosso State] |.XI.1966 | Lenko \& Pereira”. Preservation: Pinned, head glued on a plastic triangle, and abdomen in a plastic vial pinned with the specimen. Missing parts: none.

\section{Anastrepha nascimentoi Zucchi, 1979}

Zucchi (1979a), 37 (orig. desc.); 36, fig. 6 (oviscape apex, ventral view); 38, fig. 17 (wing). Type locality: Brazil, Bahia, Cruz das Almas.

Holotype female with labels: (1) printed on violet paper: "HOLOTYPE"; (2) printed with handwritten inscription on white paper: "Anastrepha $\mid$ nascimentoi $\mid$ det. Zucchi"; (3) handwritten on white paper: "Cruz das Almas - BA [Bahia State] | frasco caça mosca $\mid$ sem data $\mid$ A. S. Nascimento col.'. Preservation: Pinned, abdomen in a plastic vial pinned with the specimen. Missing parts: none.

\section{Anastrepha reichardti Zucchi, 1979}

Zucchi (1979b), 115 (orig. desc.); 116, fig. 1 (wing); 117, fig. 3 (oviscape apex, ventral view). Type locality: Venezuela, Aragua, Rancho Grande.

Holotype female with labels: (1) handwritten on red paper: "HOLOTIPO"; (2) printed with handwritten inscription on white paper: "Anastrepha | reichardti | det. Zucchi"; (3) printed on violet paper: "Rancho Grande, Ar. | Venezuela, à luz $\mid 1100$ m, 16.XI.1968 | H. Reichardt col.”. Preservation: Pinned, abdomen in a plastic vial pinned with the specimen, and right wing with apical half partially damage. Missing parts: none.

\section{Anastrepha sagittifera Zucchi, 1979}

Zucchi (1979a), 38-39 (orig. desc.); 36, fig. 6 (oviscape apex, ventral view); 38, fig. 17 (wing). Type locality: Brazil, Bahia, Cruz das Almas.

Holotype female with labels: (1) printed on violet paper: "HOLOTYPE"; (2) printed with handwritten inscription on white paper: "Anastrepha $\mid$ sagittifer $\mid$ det. Zucchi"; (3) printed on white paper: "Baixo Guandu, ES. [Espírito Santo State] | IX. 1970 | P. C. Elias col.”. Preservation: monted at the tip of a pinned card triangle, abdomen in a plastic vial pinned with the specimen. Missing parts: both legs I, right leg II, tarsus of left leg II and left leg III.

\section{Anastrepha simulans Zucchi, 1979}

Zucchi (1979a), 39 (orig. desc.); 36, fig. 8 (oviscape apex, ventral view); 38, fig. 19 (wing). Type locality: Brazil, São Paulo, Salesópolis.

Holotype female with labels: (1) printed on violet paper: "HOLOTYPE"; (2) printed with handwritten inscription on white paper: "Anastrepha $\mid$ simulans $\mid$ det. Zucchi"; (3) printed with handwritten inscription on white paper: "BR - SP.: [Brazil - São Paulo State] SALESÓPolis | BORACEA [Boracéia] $850 \mathrm{~m} \mid$ L. TRAV. F. \& E. X. RABELLO | 24.27. Junho. 1949". Preservation: Pinned, abdomen in a plastic vial pinned with the specimen. Missing parts: left leg III.

\section{Anastrepha sinvali Zucchi, 1982}

Zucchi (1982), 251-254 (orig. desc.); 252, figs. 1 (wing detail), 2 (rasper, dorsal view), 3 (oviscape tip, ventral view), 4A (male terminalia, posterior view), 4B (male terminalia, lateral view), and 5 (ejaculatory apodeme, lateral view). Type locality: Brazil Santa Catarina, Caçador.

Holotype female with labels: (1) handwritten on red paper: "Holótipo"; (2) printed with handwritten inscription on white paper: "Anastrepha $\mid$ sinvalii $\mid$ det. Zucchi”; (3) handwritten on white paper: "Caçador - SC [Santa Catarina State] | frasco em macieira | e pessegueiro |D. N. Gassen col. | 27/III/1981". Preservation: Pinned, abdomen in a plastic vial pinned with the specimen. Missing parts: none.

\section{Anastrepha sororcula Zucchi, 1979}

Zucchi (1979a), 39 (orig. desc.); 36, fig. 9 (oviscape, ventral view); 38, fig. 20 (wing). Type locality: Brazil, São Paulo, Ribeirão Preto. 
Holotype female with labels: (1) printed on violet paper: "HOLOTYPE"; (2) printed with handwritten inscription on white paper: "Anastrepha $\mid$ sororcula $\mid$ det. Zucchi"; (3) handwritten on white paper: "Ribeirão Preto - SP [São Paulo State] | Ex goiaba | Maria M. T. da Silva col. | 07/04 [IV]/1976 [lateral inscription]". Preservation: Pinned, abdomen in a plastic vial pinned with the specimen. Missing parts: none.

Paratype male with labels (1) and (2) same as labels (2) and (3) of the Holotype respectively, with label (1) differing in the second and third lines: "sororcula $\mathrm{O}$ " $\mid$ det. Zucchi, R. A."; (3) printed with handwritten inscriptions on yellow paper: "PARATYPE $\mid O^{\prime \prime} n_{-}^{\circ} 2$ ". Preservation: Pinned. Missing parts: none.

Paratype male with labels (1), (2) and (3) as in the first Paratype, with label (2) differing in date: "20/10 [X]/1976 [lateral inscription]"; and (3) in the second line: " $O n_{-}^{\circ} l$ ". Preservation: Pinned, abdomen in a plastic vial pinned with the specimen. Missing parts: none.

Paratype female with the same labels (1), (2) and (3) as in the first Paratype, with label (1) differing in the second line: "sororcula", and (3) in the second line: " $O n_{-}^{\circ} 2$ ". Preservation: Pinned, abdomen in a plastic vial pinned with the specimen. Missing parts: left arista.

Paratype female with the same labels (1), (2) and (3) as in the third Paratype, with label (3) without the second line. Preservation: Pinned, abdomen in a plastic vial pinned with the specimen. Missing parts: none.

Five Paratype females with the same labels (1) and (3) as in the third Paratype, with label (3) without the second line; (2) handwritten on white paper: "Taiuva [Taiúva] - S.P. [São Paulo State] | goiabeira-frasco | J. C. Durigan col. | 13/04/75 [IV/1975] [lateral inscription]". Preservation: Pinned, abdomen in a plastic vial pinned with the specimen; one Paratype with left wing folded on posterior margin. Missing parts: none.

\section{Anastrepha tecta Zucchi, 1979}

Zucchi (1979b), 115 (orig. desc.); 116, fig. 2 (wing); 117, figs. 4 (holotype oviscape apex, ventral view), and 5 (Paratype oviscape apex, ventral view). Type locality: Peru, Pasamayo.

Holotype female with labels: (1) handwritten on white paper: "PASAMAYO [Peru] | 26.I.68 [1968] | C. Korytkowski"; (2) handwritten on white paper: "784.68"; (3) handwritten on red paper: "Holótipo"; (4) printed with handwritten inscription on white paper: "Anastrepha $\mid$ tecta $\mid$ det. Zucchi"; (5) printed with handwritten inscription on white paper: "Univ. Nac. Pedro Ruiz Gallo $\mid$ A. rheediae Stone 42| Det.: C. Korytkowski 68". Preservation: Pinned, terminalia in a plastic vial pinned with the specimen. Missing parts: tarsi of left legs I and III.

\section{Anastrepha tenella Zucchi, 1979}

Zucchi (1979a), 40 (orig. desc.); 36, fig. 10 (oviscape, ventral view); 38, fig. 21 (wing). Type locality: Brazil, Bahia,
Cruz das Almas.

Holotype female with labels: (1) printed on violet paper: "HOLOTYPE"; (2) printed with handwritten inscription on white paper: "Anastrepha $\mid$ tenella $\mid$ det. Zucchi"; (3) handwritten on white paper: "Cruz das Almas - BA [Bahia State $] \mid$ frasco caça mosca $\mid$ sem data $\mid$ A. S. Nascimento col.". Preservation: Pinned, terminalia in a plastic vial pinned with the specimen. Missing parts: none.

\section{Anastrepha zenildae Zucchi, 1979}

Zucchi (1979a), 40 (orig. desc.); 36, fig. 11 (oviscape, ventral view); 38, fig. 22 (wing). Type locality: Brazil, Ceará, Pacajus.

Holotype female with labels: (1) printed on violet paper: "HOLOTYPE"; (2) printed with handwritten inscription on white paper: "Anastrepha $\mid$ zenildae | det. Zucchi"; (3) handwritten on white paper: "Pacajus - Ce [Ceará State]|Ex. goiaba | Zenilda B. de Castro col. | 10/12[XII]/1976 [lateral inscription]". Preservation: Pinned, abdomen in a plastic vial pinned with the specimen. Missing parts: left leg II.

Paratype male with the labels (1) and (2) same as the labels (2) and (3) of the Holotype respectively, with label (1) differing in the second and third lines: "zenildae $O$ " | det. Zucchi, R. A."; (3) printed on yellow paper: "PARATYPE". Preservation: Pinned, abdomen in a plastic vial pinned with the specimen. Missing parts: left postpedicel.

Paratype female with labels: (1) printed on yellow paper: "PARATYPE"; with the same label (2) as in the Holotype; (3) handwritten on white paper: "Cruz das Almas | BA [Bahia State] em frasco $\mid$ sem data $\mid$ A. S. Nascimento col.”. Preservation: Pinned, abdomen in a plastic vial pinned with the specimen. Missing parts: none.

\section{Cecidochares braziliensis Aczél, 1953}

Aczél (1953), 130-133 (orig. desc.); 131, fig. 10 (head, lateral view). Type locality: Brazil, São Paulo, Campos do Jordão.

Holotype male with labels: (1) printed with handwritten inscriptions on white paper: "S. Paulo [São Paulo State] | Camp. [Campos] do Jordão | III - 946 [1946] | A Ramalho col."; (2) printed with handwritten inscriptions on white paper: "INST. M. [Instituto Miguel] LILLO | Preparación | $\mathrm{N}_{-}^{\circ} .130$ M. [montage] Ala"; (3) printed with handwritten inscriptions on white paper: "Cecidochares $\mathrm{O}^{\prime} \mid$ brasiliensis n. sp. | Dr. M. Aczél det. 19"; (4) Printed on red paper: "HOLOTIPO". Preservation: Pinned, left wing mounted on slide at IMLA [Instituto y Fundación Miguel Lillo Argentina]. Missing parts: none.

\section{Cipomyia totofusca Norrbom \& Prado, 2006}

Norrbom \& Prado, 2006: 4-7 (orig. desc.); 4, fig. 1 (wing); 5 , figs. 4 (epandrium and surstyli, posterior view), 5 (base of phallus, phallapodeme, and hypandrium, ventral view), 6 (base of phallus, phallapodeme, and hypandrium, lat- 
eral view), 7 (aculeus, ventral view), 8 (aculeus tip, ventral view), 9 (glans, lateral view) and 10 (glans, dorsal view). Type locality: Brazil, Minas Gerais, Serra do Cipó.

Holotype female with labels: (1) handwritten on white paper: "Brasil, MG, [Minas Gerais State] S. Cipó [Serra do Cipó] | Estr. Usina 733 | 14/7/94 [VII/1994] Prado Solferini Orlandi"; (2) handwritten on white paper: "Cipomyia $\mid \mathrm{H}$ [holotype] | totofusca"; (3) Printed on red paper: "Holótipo". Preservation: Pinned, left eye damaged. Missing parts: none.

Paratype male with the same labels (1) and (2) as in the Holotype, with label (2) differing in the second and third lines: "totofusca P [paratype]"; (3) Printed on green paper: "Parátipo". Preservation: Pinned. Missing parts: none.

\section{Euaresta regularis Norrbom, 1993}

Norrbom (1993), 202-205 (orig. desc.); 203, fig. 2B (wing); 204, fig. 3B (sternite 5). Type locality: Brazil, São Paulo, Barueri.

Holotype female with labels: (1) printed with handwritten inscriptions on white paper: "Barueri, | São Paulo, Brasil | 4.XII.1965 | K. Lenko col.”; (2) blue circle label; (3) printed with handwritten inscriptions on red paper: "Holotype $O \mid$ Euaresta | regularis | desig. [designation] Norrbom". Preservation: glued to the tip of a pinned card point. Missing parts: none.

Paratype male with labels: (1) printed on white paper: "São Paulo | Sumaré | M. Carrera col.”; (2) handwritten on white paper: "5-I-941 [1941]"; and with the label (3) same as the label (2) of the Holotype; (4) printed on blue paper: "PARATYPE O" | Euaresta | regularis Norrbom". Preservation: glued to the tip of a pinned card point. Missing parts: none.

Paratype female with the same labels (1), (2), (3) and (4) as in the first Paratype, with label (4) differing in the first line: "PARATYPE O". Preservation: glued to the tip of a pinned card point. Missing parts: none.

Paratype female with labels: (1) printed on white paper: "BRASIL - SÃO PAULO | Monte Alegre | Faz. N. S. [Fazenda [farm] Nossa Senhora da] Incarnação 750 ms. 14.27-X-1942 | L. Trav. F. \& Almeida"; (2) blue circle label; and (3) same as label (4) of the second Paratype. Preservation: pinned with a minutien attached to standard insect pin. Missing parts: head, right legs I and III and abdomen.

Paratype female with the same labels (1), (2) and (3) as in the third Paratype. Preservation: pinned with a minutien attached to standard insect pin. Missing parts: head and left wing.

Two Paratype females with labels: (1) printed on white paper: "Barão de Antonina| Itaporanga, SP [São Paulo State] | Brasil I.1946 | M. P. Barretto col."; and with the same labels (2) and (3) as in the third Paratype. Preservation: pinned with a minutien attached to standard insect pin. Missing parts: one Paratype without left pedicel and postpedicel; one Paratype without left antenna.
Paratype female with labels: (1) printed with handwritten inscription on white paper: "S. Paulo [São Paulo State] Camp. [Campos] do Jordão/L. Travassos $F_{-}^{\circ}+\mid$ E. Rabello | III-53 [1953] [lateral inscripton]"; and with the same labels (2) and (3) as in the third Paratype. Preservation: pinned with a minutien attached to standard insect pin. Missing parts: head and all legs except left coxa and femur III.

Paratype female with labels: printed on white paper: "M.G. [Minas Gerais State] Sapucai-mirim | Cidade Azul1400m. | 7. Nov [IX] 1953 | L. Trav F. \& M. Kuhlmann | C. Gans \& S. Medeiros"; and with the same labels (2) and (3) as in the third Paratype. Preservation: pinned with a minutien attached to standard insect pin. Missing parts: none.

Paratype female with labels: (1) printed with handwritten inscription on white paper: "SÃO PAULO | Osasco | Vulcano \& [and] | Martinez | 20.XI.55 [1955] [lateral inscription]"; and with the same labels (2) and (3) as in the third Paratype. Preservation: Pinned. Missing parts: none.

Paratype female with the same label (1) as in the Holotyoe, differing in the third line: "5.2-66 [II-1966]"; and with the same labels (2) and (3) as in the third Paratype. Preservation: Pinned. Missing parts: none.

Four Paratype males with the labels (1), (2), (3) and (4) as in the ninth Paratype, with label (1) differing in the second and third lines: "SP, [São Paulo State] Brasil | 3-II-1968", and label (3) in the first line: "PARATYPE O". Preservation: glued to the tip of a pinned card point. Missing parts: none.

Four Paratype females with the same labels as in the tenth Paratype, with label (3) differing in the first line: "PARATYPE Q". Preservation: glued to the tip of a pinned card point. Missing parts: one Paratype without apical half of the right wing.

\section{Euaresta versicolor Norrbom, 1993}

Norrbom (1993), 203 (orig. desc.); 203, 2C (wing); 204, fig. $3 \mathrm{C}$ (sternite 5), 3D (male terminalia, posterior view), 3E (male terminalia, lateral view), 3F (aedeagus, ventral view), 3G (aedeagus, lateral view). Type locality: Brazil, São Paulo, Barueri.

Holotype male with labels: (1) printed with handwritten inscription on white paper: "25-X-1955 | Barueri | S. Paulo [São Paulo State] 3528 [lateral inscription]”; (2) printed with handwritten inscription on white paper: "K. Lenko leg."; (3) printed with handwritten inscription on green paper: "Wing slide | by \# 17.IX.91 [1991] F|USNM"; (3) printed with handwritten inscription on red paper: "Holotype O" | Euaresta | versicolor | desig. Norrbom”. Preservation: glued to the tip of a pinned card point. Missing parts: none.

Paratype male with labels: (1) handwritten on white paper: "BRAZIL: São Paulo, | Barueri, 25.X.1955 | K. Lenko3528"; (2) blue circle label; (3) printed on blue paper: 
“PARATYPE O" | Euaresta | versicolor Norrbom". Preservation: glued to the tip of a pinned card point. Missing parts: none.

\section{Eutretopsis albipunctata Norrbom \& Prado, 2006}

Norrbom \& Prado (2006), 9-11 (orig. desc.): 4, fig. 2 (wing); 10, figs. 11 (aculeus, ventral view), 12 (aculeus tip, ventral view), 13 (glans, lateral view) and 14 (glans, dorsal view). Type locality: Brazil, São Paulo, Campos do Jordão.

Holotype male with labels: (1) printed on white paper: "S. Paulo [São Paulo State] | Camp. do Jordão [Campos do Jordão] |L. Travassos F. E. Rabello | III. 53 [1953 (lateral inscription)]"; (2) printed with handwritten inscription on red paper: "Holotype O" $\mid$ Eutretopsis $\mid$ albipunctata $\mid$ design. [designation] Norrbom"; (3) printed on plastic label: "USNM ENT 00213195". Preservation: Pinned, abdomen in glycerine in a plastic vial. Missing parts: none.

\section{Hexachaeta enderleini Lima, 1935}

Lima (1935), 241 (orig. desc.): plate III, figs. 11 (wing), 12 (wing) and 13 (wing), plate IV, figs. 10 (oviscape, ventral view), and 17 (female abdomen, ventral view). Type locality: Brazil, São Paulo, São Paulo.

Holotype female with labels: (1) handwritten on white paper: "347."; (2) printed with handwritten inscription on white paper: "Hexachaeta | enderleini O $\mid$ n. sp. | Costa Lima det."; (3) Printed on red paper: "TYPO [Holotype]". Preservation: Pinned. Missing parts: both postpedicel, right wing, femur, tibia and tarsi of left leg II and abdomen.

\section{Lewinsohnia magna Norrbom \& Prado, 2006}

Norrbom \& Prado (2006), 12-16 (orig. desc.); 4, fig. 3 (wing); 13, figs. 15 (habitus, dorsal view), 16 (habitus, lateral view); 14, figs. 17 (head, lateral view), 18 (aculeus, ventral view), 19 (aculeus tip, ventral view), 20 (glans, dorsal view), 21 (epandrium and surstyli, posterior view) and 22 (male terminalia, lateral view). Type locality: Brazil, Minas Gerais, Joaquim Felício, Serra do Cabral.

Holotype male with labels: (1) printed on white paper: "BRASIL, MG, [Minas Gerais State] Joaquim Felício, | Serra do Cabral, prox. Matinha $\mid 17^{\circ} 41,37^{\prime} \mathrm{S} 44^{\circ} 11,88^{\prime} \mathrm{W}$ | Lewinsohn, Prado, Santos, Silva, | 3/9/96 [IX-1996] PIC 96605"; (2) handwritten on white paper: "Lewinsohnia magna H [holotype]"; (3) Printed on red paper: "Holótipo". Preservation: Pinned. Missing parts: none.

Two Paratype males and one female with the same label (1) as in the Holotype; (2) handwritten on white paper: "PIC 96605"; (3) handwritten on white paper: "Lewinsohnia magna P [paratype]"; (4) Printed on green paper: "Parátipo". Preservation: Pinned, left wing damaged on apex. Missing parts: Paratype female without left postpedicel.

\section{Molynocoelia plumosa Norrbom, 2006}

Norrbom (2006), 60-63 (orig. desc.); 38, fig. 3 (head, lateral view); 51, fig. 31 (habitus, dorsal view); 56, fig. 40 (wing); 59, figs. 44 (epandrium and surstyli, posterior view), 46 (glans); 61, fig. 49 (aculeus, dorsal view). Type locality: Brazil, Amapá.

Holotype female with labels: (1) printed on white paper: "SERRA do NAVIO | Terr. Amapá [Amapá State] BRASIL | 19-X-1957 | K. Lenko leg."; (2) printed on white paper: "COLECAO | CAMPOS SEABRA"; (3) printed with handwritten inscription on red paper: "Holotype $ᄋ$ | Molynocoelia $\mid$ plumosa $\mid$ design. [designation] Norrbom". Preservation: Pinned, head glued on pin. Missing parts: left antenna and left leg I.

\section{Polionota parva Norrbom, 1988}

Norrbom (1988), 110-112 (orig. desc.); 111, figs. 3L (aculeus, ventral view), 3M (spermatheca); 118, fig. $6 \mathrm{H}$ (wing). Type locality: Brazil, São Paulo, Salesópolis.

Holotype female with labels: (1) printed on white paper: "Est. Biol. Boracéia | Salesópolis - S. P. [São Paulo State] | Brasil - IV.1962 | N. Papavero col.”; (2) printed on white paper: "HOLOTYPE [in red] o | Polionota | parva | desig. [designation] Norrbom XII.86 [1986]". Preservation: pinned, right wing mounted on slide. Missing parts: left wing partly missing.

\section{Rhagoletis adusta Foote, 1981}

Foote (1981), 45-46 (orig. desc.); 62, fig. 10 (head, lateral view); 63, fig. 23 (thorax, dorsal view); 66, fig. 45 (oviscape, ventral view); 68, fig. 58 (aedeagus, lateral view); 69, fig. 64 (ejaculatory apodeme, lateral view); 70, fig. 69 (surstylus, lateral view); 72, fig. 86 (wing). Type locality: Brazil, São Paulo, Serra da Cantereira.

Holotype female with labels: (1) printed on white paper: "Est. S. Paulo [São Paulo State] | Cantareira | Chapadâo [Chapadão] | Barretto col. | 8-946 [VIII-1946] [lateral inscription]"; (2) blue circle label; (3) printed with handwritten inscriptions on white paper: "Holotype [encircled in red] | Rhagoletis | adusta Foote | d. RHFoote' 7"; (4) printed on red paper: "Holótipo". Preservation: Pinned, left wing with costa area damaged. Missing parts: right wing.

Paratype sex undetermined with the same labels (1) and (2) as in the Holotype; (3) printed with handwritten inscriptions on white paper: "Para- / type [lateral inscription] | Rhagoletis | adusta Foote | d. RHFoote' 78”; (4) printed on green paper: "Parátipo". Preservation: Pinned, abdomen in microvial, right wing partially damaged on costal area. Missing parts: none.

Paratype female with the same label (1) as in the Holotype; with the label (2) same as label (3) of the first Paratype; 
(3) printed with handwritten inscriptions on white paper: "Paratype |Rhagoletis $\mid$ adusta Foote | d. RHFoote' 7"; (4) printed on green paper: "Parátipo". Preservation: specimen partially broken up, all parts glued on a white card. Missing parts: none.

\section{Rhagoletotrypeta morgantei Norrbom, 1994}

Norrbom (1994), 55 (orig. desc.); 48, fig. 6E (wing); 52, figs. 9A (male terminalia, posterodorsal view), 9B (male terminalia, lateral view), and 9E (distiphallus). Type locality: Brazil, São Paulo, Ribeirão Preto, Guatapará.

Holotype male with labels: (1) printed on white paper: "Est. S. Paulo [São Paulo State] | Rib. [Ribeirão] Preto | Guatapará | Barretto col. | 1-945 [I-1945] [lateral inscription]"; (2) printed with handwritten inscription on red paper: "Holotype O"| Rhagoletotrypeta $\mid$ morgantei $\mid$ desig. [designation] Norrbom $\mid$ III.1993"; (3) printed with handwritten inscription on green paper: "Wing slide by \# 5-IX-91 [1991] D | USNM”. Preservation: Pinned, abdomen in a plastic vial pinned with specimen. Missing parts: none.

\section{Tomoplagia achromoptera Prado, Norrbom \& Lewinsohn, 2004}

Prado, Norrbom \& Lewinsohn (2004), 190-192 (orig. desc.); 191, fig. 1B (wing); 192, fig. 2A (female terminalia, ventral view). Type locality: Brazil, Minas Gerais, Diamantina.

Holotype female with labels: (1) printed on white paper: "BRASIL MG, [Minas Gerais State] Diamantina, | $18^{\circ} 9,58^{\prime} \mathrm{S} 44^{\circ} 43,01^{\prime} \mathrm{W} \mid \mathrm{T}$. Lewinsohn, M. Lopes, B. Buys, | J. Silva, 15/4/96 [IV-1996] PIC 96420"; (2) printed on red paper: "Holótipo"; (3) handwritten on white paper: "Tomoplagia | acromoptera". Preservation: Pinned. Missing parts: tarsomeres two to five of left leg III.

Paratype female with labels: (1) printed on white paper: "BRASIL MG, [Minas Gerais State] Joaquim Felício, | Serra do Cabral $\mid 17^{\circ} 42,43^{\prime}$ S $44^{\circ} 11,52^{\prime} \mathrm{W} \mid \mathrm{T}$. Lewinsohn, M. Lopes, B. Buys, | J. Silva, 13/4/96 [IV-1996] PIC 96359"; (2) handwritten inscription on white paper: "PIC 196359"; (3) handwritten on white paper: "LAM K-Y-O 194"; (4) printed on green paper: "Parátipo"; (5) handwritten on white paper: "Tomoplagia P [paratype] achromoptera". Preservation: Pinned. Missing parts: right wing and tibia and tarsus of left leg II.

Paratype female with the same label (1) as in the Holotype, differing in the fourth line: "J. Silva, 19/4/96 [IV-1996] PIC 96472"; (2) handwritten on white paper: "PIC | 96472"; (3) printed on green paper: "Parátipo"; (4) handwritten inscription on white paper: "Tomoplagia | achromoptera P [paratype]”. Preservation: Pinned. Missing parts: right postpedicel.

\section{Tomoplagia aczeli \\ Prado, Norrbom \& Lewinsohn, 2004}

Prado, Norrbom \& Lewinsohn (2004), 192-195 (orig. desc.); 191, fig. 1A (wing); 193, fig. 3A (female terminalia, ventral view); 194, fig. 4A (abdomen, dorsal view). Type locality: Brazil, Minas Gerais, Diamantina.

Holotype female with labels: (1) printed on white paper: "BRASIL MG, [Minas Gerais State] Diamantina, Estr.

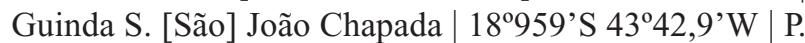
Prado, T. Lewinsohn, B. Buys, | V. Motta 27/7/95 [VII1995] PIC95415"; (2) handwritten on white paper: "FIG. 4F"; (3) printed on red paper: "Holótipo"; (4) handwritten on white paper: "Tomoplagia | aczeli". Preservation: Pinned. Missing parts: none.

One Paratype male and one female with the same labels (1) and (3) as in the Holotype, with label (3) differing in the second line: aczeli P [paratype]"; (2) printed on green paper: "Parátipo. Preservation: Pinned. Missing parts: none.

\section{Tomoplagia bicolor}

\section{Prado, Norrbom \& Lewinsohn, 2004}

Prado, Norrbom \& Lewinsohn (2004), 195-196 (orig. desc.); 191, fig. 1C (wing); 192, fig. 2C (female terminalia, ventral view); 193, fig. 3B (female terminalia, ventral view); 194, fig. 4B (abdomen, dorsal view). Type locality: Brazil, Minas Gerais, Joaquim Felício.

Holotype female with labels: (1) printed on white paper: "BRASIL MG, [Minas Gerais State] Joaquim Felício, Serra do Cabral, cerrado | 17\% $42,6^{\prime} \mathrm{S} 44^{\circ} 11,7^{\prime} \mathrm{W} \mid \mathrm{T}$. Lewinsohn, P. Prado, B. Buys, | V. Motta 19/7/1995 [VII1995] PIC 95324"; (2) printed on red paper: "Holótipo"; (3) handwritten on white paper: "Tomoplagia | bicolor". Preservation: Pinned. Missing parts: none.

Paratype female with labels: (1) printed on white paper: "BRASIL MG, [Minas Gerais State] Grão-Mogol,

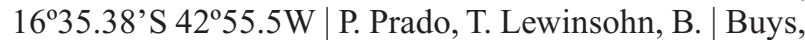
13/2/95 [II-1995]"; (2) printed on green paper: "Parátipo"; (3) handwritten on white paper: "Tomoplagia | bicolor P [paratype]". Preservation: Pinned, abdomen in a plastic vial pinned with the specimen. Missing parts: none.

\section{Tomoplagia brasiliensis \\ Prado, Norrbom \& Lewinsohn, 2004}

Prado, Norrbom \& Lewinsohn (2004), 197-198 (orig. desc.); 193, fig. 3C (female terminalia, ventral view); 194, figs. 4C (female abdomen, dorsal view), and 4D (male abdomen, dorsal view); 197, fig. 5A (male terminalia, dorsal view); 198, figs. 6A (wing), 6B (head, lateral view) and 6C (male fore tarsus, anterior view). Type locality: Brazil, Rio Grande do Sul, Capão Novo. 
Holotype female with labels: (1) printed on white paper: "BRASIL, RS [Rio Grande do Sul State], Capão Novo, | campo | 2940,52' S 4958,46' W | Lewinsohn, Prado, Macedo, | Batista, 10/02/96 [II/1996] PIC 96039"; (2) printed on red paper: "Holótipo"; (3) handwritten on white paper: "Tomoplagia | brasiliensis". Preservation: Pinned. Missing parts: none.

Paratype male with the same label (1) as in the Holotype; (2) handwritten on white paper: "PIC 96039"; (3) printed on green paper: "Parátipo"; (4) handwritten on white paper: "FIG. 4B"; (5) handwritten on white paper: "Tomoplagia | brasiliensis P [Paratype]". Preservation: Pinned. Missing parts: tarsomeres three to five of both legs I and tarsomeres two to five of right leg III.

Paratype female with labels: (1) printed on white paper: "BRASIL, SC [Santa Catarina State], Lages, Estrada de S. [São] José do Cerrito | 27041,88’ S 50³2,56’ W | Lewinsohn, Prado, Macedo, | Batista, 15/02/96 [II/1996] PIC 96163"; and with the same labels (2) and (3) as in the first Paratype, with label (2) differing in: "PIC | 96163"; label (4) same as label (5) of the first Paratype. Preservation: Pinned. Missing parts: none.

\section{Tomoplagia carrerai Aczél, 1955}

Aczél (1955), 341-344 (orig. desc.); 371, figs. 96a (head, lateral view), 96b (epandrium, dorsal view), and 96c (maxillary palpus, lower view); 375, fig. 97j (male abdomen, dorsal view); plate 21, fig. 9 (wing). Type locality: Brazil, São Paulo, Castelhanos.

Holotype male with labels: (1) handwritten on white paper: "Castelhanos | 28-VII-36 [1936]"; (2) printed on white paper: "Lange de Morretes | coll. 1936"; (3) printed with handwritten inscription on white paper: "Tomoplagia $O^{\prime \prime}$ carrerai $n$. sp. | Dr. M. Aczél det.”; (4) handwritten on red paper: "Holotype". Preservation: Pinned, both wings damaged on middle of costal vein. Missing parts: left arista.

\section{Tomoplagia cipoensis \\ Prado, Norrbom \& Lewinsohn, 2004}

Prado, Norrbom \& Lewinsohn (2004), 199-200 (orig. desc.); 191, fig. 1D (wing); 193, fig. 3D (female terminalia, ventral view); 194, figs. 4H (thorax, dorsal view), and 4I (palpus). Type locality: Brazil, Minas Gerais, Santana do Riacho.

Holotype male with labels: (1) printed on white paper: "Brasil, MG, [Minas Gerais State], Santana do Riacho | Serra do Cipó | 19²13,91' S 4330,37' W | P. Prado, T. Lewinsohn, B. Buys, | V. Motta 26/7/95 [VII/1995] PIC 95442"; (2) printed on red paper: "Holótipo"; (3) handwritten on white paper: "FIG. 4I/4H"; (4) handwritten on white paper: "Tomoplagia | cipoensis". Preservation: Pinned, with an incision on costal area of left wing. Missing parts: none.
Paratype female with labels: (1) printed with handwritten inscription on white paper: "Serra do Cipó. MG, [Minas Gerais State] - BRASIL | Rod. [road] MG 10 KM 117. 562 | ex Vernonia vepetorum | 28/5/92 [V/1992] Paulo Prado leg"; (2) printed on green paper: "Parátipo"; (3) handwritten on white paper: "Tomoplagia | cipoensis P [paratype]". Preservation: Pinned. Missing parts: none.

\section{Tomoplagia dimorphica \\ Prado, Norrbom \& Lewinsohn, 2004}

Prado, Norrbom \& Lewinsohn (2004), 200-201 (orig. desc.); 191, figs. 1E (male wing), and 1F (female wing); 193, fig. 3E (female terminalia, ventral view). Type locality: Brazil, Minas Gerais, Joaquim Felício.

Holotype female with labels: (1) printed on white paper: "BRASIL, MG, [Minas Gerais State] Joaquim Felício, | Serra do Cabral, vale córr. [córrego] Jucão | 17041.91' S 44¹6.66' W | Lewinsohn, Prado, Santos, Silva, | 2/9/96 [IX-1996] PIC 96584"; (2) printed on red paper: "Holótipo"; (3) handwritten on white paper: "Tomoplagia | dimorphica". Preservation: Pinned, costal area of left wing partially damaged. Missing parts: left leg II and tarsomeres two to five of right leg II.

Paratype male with the same labels (1) and (3) as in the Holotype, with label (3) differing in the second line: "dimorphica P [paratype]"; (2) printed on green paper: "Parátipo". Preservation: Pinned. Missing parts: left leg III.

\section{Tomoplagia grandis \\ Prado, Norrbom \& Lewinsohn, 2004}

Prado, Norrbom \& Lewinsohn (2004), 201-202 (orig. desc.); 191, fig. $1 \mathrm{G}$ (wing); 193, fig. 3F (female terminalia, ventral view); 194, figs. 4E (female abdomen, dorsal view), and 4F (male abdomen, dorsal view); 197, fig. 5B (male terminalia, dorsal view). Type locality: Brazil, Minas Gerais, Joaquim Felício.

Holotype female with labels: (1) printed on white paper: "BRASIL, MG, [Minas Gerais State] Joaquim Felício, | Serra do Cabral $\mid 17^{\circ} 43.61^{\prime}$ S $44^{\circ} 11.01^{\prime}$ 'W $\mid$ T. Lewinsohn, M. Lopes, B. Buys, | J. Silva, 13/4/96 [IV-1996] PIC 96344”; (2) printed on red paper: "Holótipo"; (3) handwritten on white paper: "FIG. 4C|"; (4) handwritten on white "Tomoplagia | grandis". Preservation: Pinned. Missing parts: none.

Paratype female with the same label (1) as in the Holotype; (2) printed on green paper: "Parátipo"; label (3) same as label (4) of the Holotype. Preservation: Pinned, abdomen in a plastic vial pinned with the specimen. Missing parts: none.

\section{Tomoplagia interrupta \\ Prado, Norrbom \& Lewinsohn, 2004}

Prado, Norrbom \& Lewinsohn (2004), 202-203: (orig. desc.); 191, fig. $1 \mathrm{H}$ (wing); 193, fig. $3 \mathrm{G}$ (female terminalia, ven- 
tral view); 194, fig. 4J (head, lateral view). Type locality: Brazil, Minas Gerais, Diamantina.

Holotype female with labels: (1) printed on white paper: "BRASIL MG, [Minas Gerais State] Diamantina, | Estr. Cons. Matta $\mid 18^{\circ} 17.89^{\prime}$ S 4350,01' W | P. Prado, T. Lewinsohn, B. | Buys, 18/02/95 [II-1995], PIC95074”; (2) printed on red paper: "Holótipo"; (3) handwritten on white paper: "FIG. 4J"; (4) handwritten on white paper: "Tomoplagia | interrupta". Preservation: Pinned, incision on costal area of right wing. Missing parts: none.

Paratype male with the same label (1) as in the Holotype, differing in the fifth line: "Buys, 18/02/95 [II-1995], PIC95073"; (2) printed on green paper: "Parátipo"; (3) handwritten on white paper: "Tomoplagia / interrupta P [paratype]". Preservation: Pinned. Missing parts: left leg II.

Paratype male with labels: (1) printed on white paper: "BRASIL MG, [Minas Gerais State] Diamantina, S. J. | Chapada, Serra da Guiné | 186,54' S 4344,09' W | T. Lewinsohn, M. Lopes, B. Buys, | J. Silva, 17/4/96 [IV1996], PIC 965424"; (2) handwritten on white paper: "PIC 965424"; and labels (3) and (5) same as labels (2) and (3) of the first Paratype respectively; (4) handwritten on white paper: "FIG. 1L". Preservation: Pinned, abdomen in a plastic vial pinned with the specimen. Missing parts: left legs I and II, tarsomeres two to five of right leg III and tibia and tarsus of left leg III.

\section{Tomoplagia matzenbacheri Prado, Norrbom \& Lewinsohn, 2004}

Prado, Norrbom \& Lewinsohn (2004), 203-204 (orig. desc.); 191, fig. 1I (wing); 193, fig. 3H (female terminalia, ventral view); 194, fig. 4G (male abdome, dorsal view). Type locality: Brazil, Rio Grande do Sul, Guaiba.

Holotype female with labels: (1) printed on white paper: "BRASIL, RS, [Rio Grande do Sul State] Guaiba, Sítio S. | Maximiano, BR - 116 km $31 \mid 30^{\circ} 10.84^{\prime} \mathrm{S} 51^{\circ} 23.52^{\prime}$ W | P. Prado, T. Lewinsohn, A. | Macedo, 8/4/95 [IV-1995], PIC95121"; (2) printed on red paper: "Holótipo"; (3) handwritten on white paper: "Tomoplagia | matzenbacheri". Preservation: Pinned. Missing parts: none.

Paratype male with the same label (1) as in the Holotype; (2) printed on green paper: "Parátipo"; (3) handwritten on white paper: "FIG. 4E"; and label (4) the same as label (3) of the Holotype. Preservation: Pinned. Missing parts: tarsus of left leg I.

\section{Tomoplagia ovalipalpis Aczél, 1955}

Aczél (1955), 374-377 (orig. desc.); 383, figs. 100a (female postabdome, lateral view), 100b (oviscape, lateral view), 100c (oviscape, dorsal view), 100d (maxillary palpus, inferior view), and 100e (head, lateral view); 399, fig. 102w (female abdomen, dorsal view); plate 24, fig. 20 (wing). Type locality: Brazil, São Paulo, Itanhaém.
Holotype male with labels: (1) handwritten on white paper: "S. Paulo [São Paulo State] Itanhaem | E. Rabello|XI-948 [1948] [lateral inscription]"; (2) printed with handwritten inscription on white paper: "INST. M. LILLO $\mid$ Preparación $\mid \mathrm{N}^{\mathrm{o}} 82 \mathrm{M}$. Ala"; (3) printed with handwritten inscription on white paper: "Tomoplagia $q$ | ovalipalpis $n . s p$. | Dr. M. Aczél det. 19"; (4) handwritten on red paper: "Holótipo". Preservation: Pinned. Missing parts: right wing.

\section{Tomoplagia pallens}

\section{Abreu, Prado, Norrbom \& Solferini, 2005}

Abreu, Prado, Norrbom \& Solferini (2005), 367-368 (orig. desc.); 366, figs. 3A (abdomen, dorsal view), and 3C (aculeus, ventral view); 367, fig. 5B (male terminalia glans). Type locality: Brazil, Goías, Pirenópolis.

Holotype female with labels: (1) handwritten on white paper: "KSY0107"; (2) printed on red paper: "Holótipo"; (3) handwritten on white paper: "Brasil: Goías | Pirenópolis 13/6/ [VI] 2001 | Abreu \& Yotoko, col. | KSY 0107”; (4) handwritten on white paper: "Tomoplagia | pallens". Preservation: Pinned. Missing parts: tarsus of right leg I, femora, tibiae and tarsi of legs II and both tarsi of legs III.

Paratype male with the same labels (1), (3) and (4) as in the Holotype, with label (4) differing in the second line: "pallens P [paratype]"; (2) printed on green paper: "Parátipo". Preservation: Pinned. Missing parts: right postpedicel, both tarsi of leg I and tarsus of right leg III.

\section{Tomoplagia reticulata}

\section{Abreu, Prado, Norrbom \& Solferini, 2005}

Abreu, Prado, Norrbom \& Solferini (2005), 365-367 (orig. desc.); 366, figs. 3B (abdomen, dorsal view), and 3D (aculeus, ventral view); 367, figs. 4 (wing), and 5A (male terminalia glans). Type locality: Brazil, Minas Gerais, Santana do Riacho.

Paratype male with labels: (1) printed on white paper: "BRASIL MG, [Minas Gerais State] Joaquim Felício, | Serra do Cabral, Faz. Da Onça | 17041.94' S 44²14.82' W | Lewinsohn, Prado, Santos, Silva | 3/9/96 [IX/1996] PIC 96601"; (2) handwritten on white paper: "PIC 96601"; (3) printed on green paper: "Parátipo". Preservation: Pinned. Missing parts: none.

One Paratype female and two of undetermined sex with the same labels (1) and (3) as in the first Paratype; (2) handwritten on white paper: "Tomoplagia | reticulata Abreu | et al.". Preservation: Pinned. Missing parts: Paratype female without left wing.

\section{Tomoplagia rupestris Prado, Norrbom \& Lewinsohn, 2004}

Prado, Norrbom \& Lewinsohn (2004), 204-206 (orig. desc.); 191, fig. 1J (wing); 193, fig. 3I (female terminalia, ven- 
tral view); 197, fig. 5D (male terminalia glans). Type locality: Brazil, Minas Gerais, Diamantina.

Holotype female with labels: (1) printed on white paper: "BRASIL, MG, [Minas Gerais State] Diamantina, 18¹1.96’ S 4342,56’ W| T. Lewinsohn, M. Lopes, B. Buys, | J. Silva, 19/4/96 [IV/19996] PIC 96478"; (2) handwritten on white paper: "PIC | 96478"; (3) printed on red paper: "Holótipo"; (4) handwritten on white paper: "Tomoplagia | rupestris". Preservation: Pinned. Missing parts: none.

Paratype male with labels: (1) printed on white paper: "BRASIL, MG, [Minas Gerais State] Santana do Riacho, | S. [Serra do] Cipó, Chapéu do Sol, campo | ${ }^{\circ}$ ' ${ }^{\circ}$ ' W | Bruno D. Buys, 11/3/96 [III/19996] | PIC 96268"; (2) printed on green paper: "Parátipo"; and label (3) same as label (4) of the Holotype, differing in the second line: "rupestris P [paratype]". Preservation: Pinned. Missing parts: tarsomeres two to five of right leg II, tarsus of right leg III and tarsomeres two to five of left leg III.

Paratype female with labels: (1) printed on white paper: "BRASIL, MG, [Minas Gerais State] Diamantina, S. J. [São João] | Chapada, Serra da Guiné | 18º,6’ S 43%4,08' W | Lewinsohn, Prado, Santos, Silva, | 7/9/96 [VII/1996] | PIC 9676"; (2) handwritten on white paper: "PIC96676"; (3) printed on green paper: "Parátipo"; (4) handwritten on white paper: "Tomoplagia | rupestris P [paratype]". Preservation: Pinned. Missing parts: none.

Paratype female with the same labels (1), (2) and (4) as in the Holotype, with label (4) differing in the second line: "rupestris P [paratype]"; (3) same as above. Preservation: Pinned, abdomen in a plastic vial pinned with the specimen. Missing parts: right wing, left legs I, II and III and tarsomeres two to five of right leg III.

\section{Tomoplagia salesopolitana Aczél, 1955}

Aczél (1955), 400-402 (orig. desc.); 397, figs. 101e (maxillary palpus, inferior view), and $101 \mathrm{f}$ (head, lateral view); 399, fig. $102 \mathrm{f}$ (male abdomen, dorsal view); plate 26, fig. 26 (wing). Type locality: Brazil, São Paulo, Salesópolis.

Holotype male with labels: (1) printed on white paper: "BRS.P [Brazil-São Paulo State].: Salesópolis | (Boracea) [Boracéia] 14.VIII.1947 | E. Rabello \& Trav. Fo | \& J. Lane"; printed with handwritten inscription on white paper: "Tomoplagia $\mathrm{O}^{\text {" }}$ salesopolitana n. sp. | Dr. M. Aczél det. 19"; (4) handwritten on red paper: "Holotipo". Preservation: Pinned. Missing parts: tarsomeres two to five of left leg II.

\section{Tomoplagia variabilis \\ Prado, Norrbom \& Lewinsohn, 2004}

Prado, Norrbom \& Lewinsohn (2004), 206-207 (orig. desc.); 191, fig. 1L (wing); 193, fig. 3J (female terminalia, ventral view). Type locality: Brazil, Minas Gerais, Joaquim Felício. Holotype female with labels: (1) printed on white paper:
"BRASIL, MG, [Minas Gerais State] Joaquim Felício, | Serra do Cabral, vale córr. [Córrego] Jucão | 17²41.91' S 44 ${ }^{\circ} 16.66^{\prime}$ W | Lewinsohn, Prado, Santos, Silva, | 2/9/96 [II-1996] PIC 96584"; (2) printed on red paper: "Holótipo"; (3) handwritten on white paper: "Tomoplagia | variabilis". Preservation: Pinned. Missing parts: none.

One Paratype male and two females with the same labels (1) and (3) as in the Holotype, with label (3) differing in the second line: "variabilis P [paratype]"; (2) printed on green paper: "Parátipo". Preservation: Pinned. Missing parts: Paratype male without left postpedicel.

\section{Tomoplagia voluta \\ Prado, Norrbom \& Lewinsohn, 2004}

Prado, Norrbom \& Lewinsohn (2004), 207-208 (orig. desc.); 191, fig. $1 \mathrm{M}$ (wing); 193, fig. 3K (female terminalia, ventral view); 197, figs. 5C (male terminalia, dorsal view) and 5E (male terminalia glans). Type locality: Brazil, Minas Gerais, Santana do Riacho.

Holotype female with labels: (1) handwritten on white paper: "PIC | 96268"; (2) “Tomoplagia | voluta"; (3) printed on red paper: "Holótipo". Preservation: Pinned. Missing parts: none.

Paratype male with labels: (1) printed on white paper: "BRASIL, MG, [Minas Gerais State] Joaquim Felício, | Serra do Cabral $\left|17^{\circ} 43.61^{\prime} \mathrm{S} 44^{\circ} 11.01^{\prime} \mathrm{W}\right| \mathrm{T}$. Lewinsohn, M. Lopes, B. Buys, | J. Silva, 13/4/96 [IV/19996] PIC 96342"; (2) handwritten on white paper: "PIC | 96342"; (3) printed on green paper: "Parátipo"; (4) handwritten on white paper: "Tomoplagia | voluta P [paratype]". Preservation: Pinned, abdomen in a plastic vial pinned with the specimen. Missing parts none.

\section{ACKNOWLEDGEMENTS}

The authors are grateful to Dr. Allen L. Norrbom (USDA) for sending information concerning material on loan to his care; to Dr. Thomas M. Lewinsohn (UNICAMP), Dr. Paulo I. Prado (USP), and Dr. Roberto A. Zucchi (USP) for cordially receiving the authors on visits to analyse type material of MZUSP on loan and under their care; and also to the Conselho Nacional de Desenvolvimento Científico e Tecnológico (CNPq) for the PhD fellowship to RLM and for the grant to CJEL (Proc. No. 481024/2008-5).

\section{REFERENCES}

Abreu, A. G.; P. I. Prado; A. L. Norrbom \& V. N. Solferini. 2005. Genetic and morphological diagnosis and description of two cryptic species of flower head-infesting Tephritidae (Diptera). Insect Systematics \& Evolution 36: 361-370.

Aczél, M. 1953. La familia Tephritidae en la region neotropical I (Trypetidae, Diptera). Acta Zoologica Lilloana 13: 97-199.

Aczél, M. 1955. Fruit flies of the genus Tomoplagia Coquillett (Diptera, Tephritidae). Proceedings of the United States National Museum 104: $321-411$. 
Aczél, M. 1956a. Revisíon parcial de las Pyrgotidae neotropicales y antárticas con synopsis de los géneros y especies (Diptera, Acalyptratae). Revista Brasileira de Entomologia 5: 1-70.

Aczél, M. 1956b. Revisíon parcial de las Pyrgotidae neotropicales y antárticas con synopsis de los géneros y especies (Diptera, Acalyptratae). Revista Brasileira de Entomologia 6: $1-38$.

Aczél, M. 1961. A revision of American Neriidae (Diptera, Acalyptrata). Studia Entomologica 4: 257-346.

Albuquerque, L. P. 1967. Sobre três espécies de 'Protylos' Aczél (Diptera: Micropezidae). Revista Brasileira de Biologia 27: 233-245.

Bernardi, N. 1991. Notas sobre o gênero Leptopyrgota Hendel, com descrição de vinte e uma novas espécies do Brasil (Diptera, Pyrgotidae). Revista Brasileira de Zoologia 7: 327-350.

Camras, S. \& P. P. Parrillo. 1985. Review of New World Stylogaster (Diptera: Conopidae). Annals of the Entomological Society of America 78: 111-126.

Foote, R. H. 1981. The genus Rhagoletis Loew South of the United States (Diptera: Tephritidae). United States Department of Agriculture Technical Bulletin, Supplement 1607: 1-75.

ICZN (International Commission on Zoological Nomenclature). 1999. International Code of Zoological Nomenclature. Fourth edition, adopted by the International Union of Biological Sciences. London, International Trust for Zoological Nomenclature, The Natural History Museum, $\mathrm{xxx}+306 \mathrm{p}$.

Lima, A. M. C. 1935. Notas sobre trypetidas brasileiras. Moscas do gênero Hexachaeta Loew. Academia Brasileira de Ciências 7: 235-250.

Lopes, H. de S. \& L. Monteiro. 1959. Sobre algumas espécies brasileiras de Stylogaster Macquart, com descrição de quatro espécies novas (Diptera, Conopidae). Studia Entomologica 2: 1-24.

McAlpine, J. F. 1981. Morphology and terminology - adults, p. 9-63. In: J. F. McAlpine; B. V. Peterson; G. E. Shewell; H. J. Teskey; J. R. Vockeroth \& D. M. Wood (eds.). Manual of Nearctic Diptera. Ottawa, Research Branch Agriculture Canada, Monograph 27, vol. 1, vi+674 p.

McAlpine, J. F. 1989. Phylogeny and classification of the Muscomorpha, 1397-1518. In: J. F. McAlpine \& D. M. Wood (eds.). Manual of Nearctic Diptera. Ottawa, Research Branch Agriculture Canada, Monograph 32, vol. 3, vi+248 p.

Mello, R. L. \& C. J. E. Lamas. 2008. Review of the monotypic genus Idiopyrgota Aczél (Diptera, Pyrgotidae). Zootaxa 1817: 59-64.

Mello, R. L.; C. J. E. Lamas \& J. E. Rafael. 2010. Revision of the Neotropical genus Carrerapyrgota Aczél (Diptera, Pyrgotidae) with the description of two new species. Zootaxa 2515: 45-64.

Monteiro, L. 1960. Insecta Amapaensia. Diptera Conopidae: espécies do gênero Stylogaster Macquart, 1835. Memórias do Instituto Oswaldo Cruz 58: 103-114.

Norrbom, A. L. 1988. A revision of the Neotropical genus Polionota Wulp (Diptera: Tephritidae). Folia Entomologica Mexicana 73: 101-123.

Norrbom, A. L. 1993. New species and phylogenetic analysis of Euaresta
Loew (Diptera: Tephritidae), with a key to the species from the Americas south of Mexico. Proceedings of the Entomological Society of Washington 95: 195-209.

Norrbom, A. L. 1994. New species and phylogenetic analysis of Cryptodacus, Haywardina, and Rhagoletotrypeta (Diptera: Tephritidae). Insecta Mundi 8: $37-65$.

Norrbom, A. L. 2006. A revision of the Neotropical genera Molynocoelia Giglio-Tos, Pseudophorellia Lima, and Alujamyia n. gen. (Diptera: Tephritidae). Israel Journal of Entomology 35/36: 35-145.

Norrbom, A. \& J. F. McAlpine. 1997. A revision of the Neotropical species of Dasiops Rondani (Diptera: Lonchaeidae) attacking Passiflora (Passifloraceae). Memoirs of the Entomological Society of Washington 18: 189-211.

Norrbom, A. \& P. I. Prado. 2006. New genera and host plant records of Asteraceae-feeding Tephritidae (Diptera) from Brazil. Zootaxa 1139: $1-17$.

Papavero, N. 1970. Novo gênero de Dalmanniinae do Brasil (Diptera, Conopidae). Papéis Avulsos de Zoologia 13: 121-125.

Papavero, N. \& F. C. Val. 1971. A New Thyreophoridae of Brazilian Amazon (Diptera, Acalyptratae). Papéis Avulsos de Zoologia 25: 105-109.

Prado, A. P. 1969. Syringogastridae, uma nova família de dípteros Acalyptratae, com a descrição de seis espécies novas do gênero Syringogaster Cresson. Studia Entomologica 12: 1-32.

Prado, P. I.; A. L. Norrbom \& T. M. Lewinsohn. 2004. New species of Tomoplagia Coquillett (Diptera: Tephritidae) from capitula of Asteraceae in Brazil. Neotropical Entomology 32: 189-211.

Ribeiro, G. C.; C. J. E. Lamas \& L. N.S. Azevedo. 2007. A catalogue of the types of Limoniidae and Tipulidae (Diptera: Tipulomorpha) in the collection of the Museu de Zoologia da Universidade de São Paulo, Brazil. Zootaxa 1497: 1-22.

Strikis, P. C. \& A. P. Prado. 2005. A new species of the genus Neosilba (Diptera: Lonchaeidae). Zootaxa 828: $1-4$

Stuckenberg, B. R. 1999. Anntenal evolution in the Brachycera (Diptera), with a reassessement of terminology relating to the flagellum. Studia Dipterologica 6: 33-48

Yeates, D. K. \& B. M. Wiegmann. 1999. Congruence and controversy: toward a higher-level phylogeny of Diptera. Annual Review of Entomology 44: 397-428.

Zucchi, R. A. 1979a. Novas espécies de Anastrepha Schiner, 1868 (Diptera: Tephritidae). Revista Brasileira de Entomologia 23: 35-41.

Zucchi, R. A. 1979b. Duas novas espécies de Anastrepha Schiner, 1868 (Diptera: Tephritidae). Revista Brasileira de Entomologia 23: 115-118.

Zucchi, R. A. 1982. A new species of fruitfly of the genus Anastrepha Schiner, 1868 (Dip., Tephritidae) from Brazil. Anais da Sociedade Entomológica do Brasil 11: 251-254.

Zucchi, R. A. 1984. Nova espécie de Anastrepha (Diptera, Tephritidae) da região Amazonica. Anais da Sociedade Entomológica do Brasil 13 279-280.

Received 23/6/2010; accepted 19/4/2011

Editor: Silvio Shigueo Nihei 